Portland State University

PDXScholar

7-20-1977

\title{
Office Simulation Survey with Plan of Implementation
}

Arlene B. Krause

Portland State University

Follow this and additional works at: https://pdxscholar.library.pdx.edu/open_access_etds

Part of the Business Administration, Management, and Operations Commons, Educational Methods Commons, and the Human Resources Management Commons Let us know how access to this document benefits you.

\section{Recommended Citation}

Krause, Arlene B., "Office Simulation Survey with Plan of Implementation" (1977). Dissertations and Theses. Paper 2603.

https://doi.org/10.15760/etd.2598

This Thesis is brought to you for free and open access. It has been accepted for inclusion in Dissertations and Theses by an authorized administrator of PDXScholar. Please contact us if we can make this document more accessible: pdxscholar@pdx.edu. 
AN ABSTRACT OF THE THESIS OF Arlene B. Krause for the Naster of Science in Teaching in Business Education presented July 20, 1977.

Title: Office Simulation Survey with Plan of Implenentation. APPROVED BY MEMBERS OF THE TIESIS COMMTTEE:

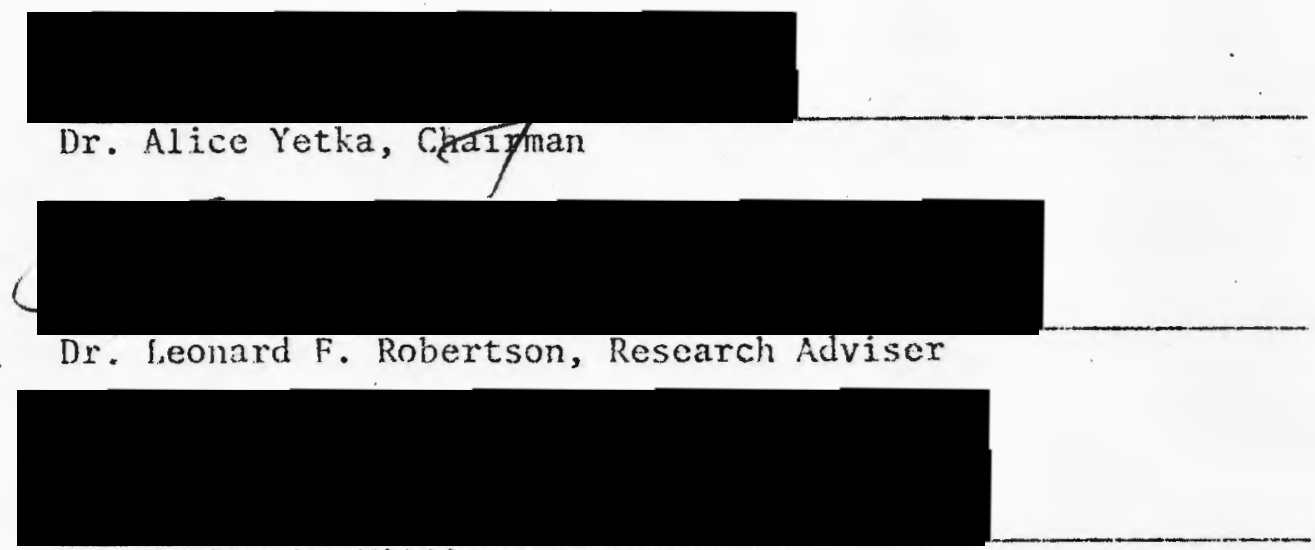

Dr. Forbes W. Willians

\section{Statement of the Problem}

The problem involved in this study was to ascertain the current methods and materials used by office simulation teachers in the secondary schools of the State of Oregon and to suggest a plan to implement a similated office program in the Reynolds School District.

Resume of Data and Manner in which it was Obtained

Questionnaires were sent to 170 Oregon teachers of office practice. One hundred and fifty-six questionnaires vere returned.

Questions were asked as to how the class was set up, the materials and equipment used, the size of the school and class, requirements of the 
class, evaluation criteria, why the program was implemented, the objectives, problems encountered, and promotional methods used.

In addition to the survey, related literature and simulated materials were reviewed to obtain information for developing a plan of implementation of an office simulation program in the Reynolds School District.

\section{Summary of Results}

The following infornation was concluded from the questionnaire:

1. Sixty-five per cent of the teachers responding to the questionnaire teach office simulation. Forty-six per cent of these teachers teach the class independent of other classes.

2. Most teachers require Typing I as a prerequisite and students who are at least in their junior year of school.

3. Mlost schools offer office simulation one period per day, five days a week.

4. Lester Hill Corporation and materials prepared by individual teachers are the most frequently used materials.

5. Host of the equipment used for office simulation is equipment already in use in the business classrooms.

6. The most popular length of time at one job position is four weeks.

7. Host teachers select the students for job positions through student applications and interviews.

8. In classes including simulation units, quality of work, mailability, and attitude were the three top ranked evaluation criteria. In the independent simulation class, quality of work, effort and improvement, and cooperation were ranked at the top. 
9. Office simulation classes most frequently offered two credits for ten hours per week for a full ycar and one credit for five hours per week for a full year.

10. The majority of the schools offering office simulation are over 500 students and have 11 to 20 students in the class.

11. The majority of the schools offering office simulation have one or two classes.

12. Work-flow experience, depending on the work of others, and coordinating skills with denands on the job are facets of office simulation which are not learned in other classes.

13. Office simulation was implemented in many of the schools because of a teacher desire.

14. The top ranked objectives were to help students develop desirable work habits such as ability to organize, to follow directions, and to be thorough and efficient and to develop acceptable character, personality traits, and work habits important to the business office.

15. Most office simulation teachers in Oregon feel that the program is meeting the objectives desired.

16. Scheduling difficulties and teacher preparation time are the two main problems faced by teachers in setting up a simulation prograr.

17. Student recommendations, counselor recommendations, and presentations in other classes are the promotional methods used most often by the teachers of office simulation.

The following are suggested in the plan of implementation:

1. The office simulation class will be taught at Columbia High School. 
2. The class will be independent of other classes and will meet two hours per day, five days a week for a full year.

3. The simulation materials to be used are SAFECO and Lester Hill Corporation.

4. Typing I will be a prorequisite for the simulation class.

5. Students will apply for job positions and be rotated about every four weeks.

6. Class size will be limited to 28 students.

7. An advisory comittee will be organized. 
OFFICE STMULATION SURVEY

WITH PLAN OF IMPLEMENTATION

by

ARLENE B. KRAUSE

A thesis submitted in partial fulfillment of the requirements for the degree of

MASTER OF SCIENCE IN TEICHING,

in

BUSINESS EDUCATION

Portland State University

1977 
TO TIE OFFICE OF GRADUATE STUDIES AND RESEARCH:

The members of the Conmittee approve the thesis of Arlene B. Krause presented July 20, 1977.

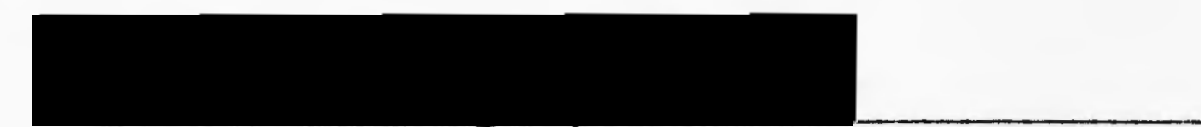

Dr. Alice Yetka, Chairfman

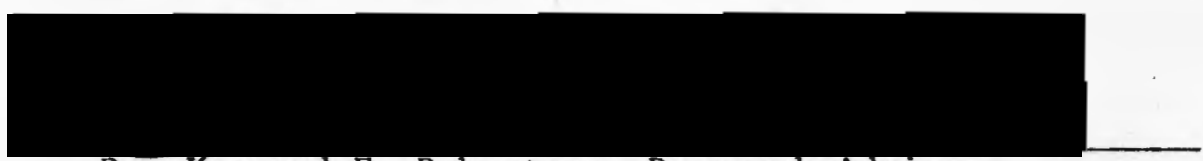

Dr: Keonard F. Robertson, Research Adviser

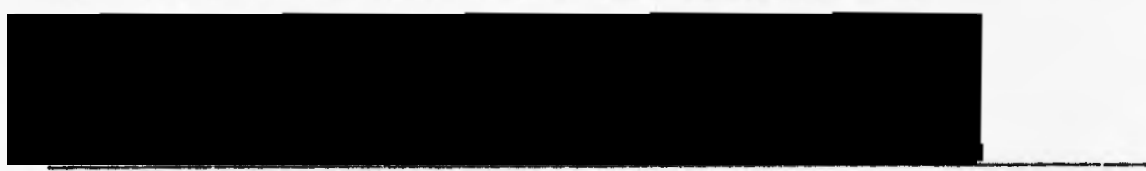

Dr. Forbes W. Williams

APPROVED:

Dr. Leonard F. Robertson, Head, Department of Business Education

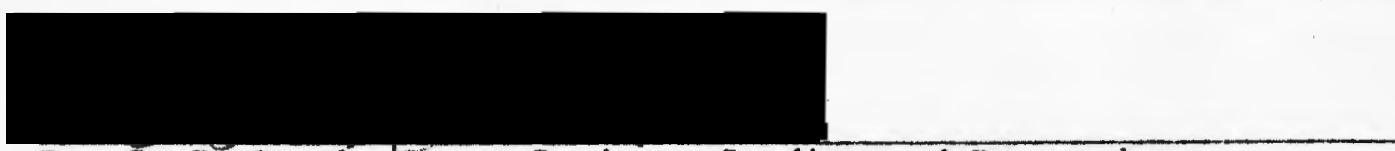

Dr. S. F. Rauch, Dean, Graduate Studies and Research 


\section{ACKNOWLEDGMENTS}

Deep gratitude is expressed to Dr. Leonard F. Robertson, my research adviser, who gave his time so willingly and made this experience an enjoyable one; and to Dr. Alice Yetka, committee chairman, who added so much to this study through her thoroughness and objectivity.

Appreciation is also extended to Dr. Forbes Williams, who read the manuscript and served as a comittee member.

To my precious Kris, who endured with much patience, love, and sacrifice, I give my eternal love.

To my departed husband, Wally, whose encouragement started me on my study for a master's degree, and whose love made our lives so complete, I pledge my eternal love. 
TABLE OF CONTENTS

PACE

ACKNOWLEDGMENTS . . . . . . . . . . . . . . . . . . iii LIST OF TABLES . . . . . . . . . . . . . . . . . . . viii CHIAPTER

I INTRODUCTION . . . . . . . . . . . . . . . 1

Need for the Study . . . . . . . . . . . 1

Statement of the Problem ............ 4

Purpose of the Study . . . . . . . . . . . . 5

Delimitations.............. . . 6

Definition of Terms . . . . . . . . . . 7

Summary .................... 8

II REVIEI OF RELATED LITERATURE . . . . . . . . . . . . 9

History of Simulation ............. . 9

Simulation Defined ... . . . . . . . . . . 12

Purposes of Simulation . . . . . . . . . . 13

Objectives of Simulation ............ . 15

Simulation Prerequisites . . . . . . . . . 16

Examples of Simulation Projects . . . . . . . 18

Teacher Responsibility ............. 21

Methods of Teaching Simulation . . . . . . . . 22 
Time . . . . . . . . . . . . . . 23

Developing a Simulated Office . . . . . . . . 24

Equipment ................. 27

Evaluation of Students . . . . . . . . . . 28

Advantages and Disadvantages of Simulation . . . . . 29

Summary . . . . . . . . . . . . . . . 31

III METHODS AND PROCEDURES . . . . . . . . . . . . . . 33

Introduction ............... 33

Research Technique . . . . . . . . . . . 33

Refinement of Instruments . . . . . . . . . 34

Selection of the Sample . . . . . . . . . . 34

Follow-up . . . . . . . . . . . . . . . 34

Treatment of the Data . . . . . . . . . . 35

Summary . . . . . . . . . . . . . . . 35

IV PRESENTATION OF TIE FINDINGS . . . . . . . . . . . . 36

Question 1--Do you have any form of office... . . . 36 simulation in your business curriculum?

Question 2--Name of simulation class . . . . . . 37

Question 3--If simulation is a part of another ... . 37 class, please give the name(s) of the class(es).

Question 4--For how long is the simulation class . . 38 taught?

Question 5--What are the prerequisites of the ... . simulation class?

Question 6--For what block of time does the ..... simulation class meet?

Question 7--What text or materials are used for ... simulation?

Question 8--What equipment is used in simulation? . 
Question 9--Rank the criteria used for evaluating . . 45 students according to the value placed on that item.

Question 10--How often are job positions rotated? . . 46

Question 11--llow are students selected for job . . . 49 positions?

Question 12--llow many credits per year are ..... 50 given simulation students?

Question 13--How many students are enrolled..... . 51 in your school?

Question 14--llow many students are enrolled..... 53 in office simulation?

Question 15--llow many classes of simulation ..... 53 are offered?

Question 16--What learning takes place that . . . . 54 students cannot get in other classes taught in your school, such as office practice and work experience?

Question 17--Why was the program implemented . . . . 57 in your school?

Question 18-- What problems were encountered in . . . 58 setting up the simulation program?

Question 19--What promotional methods are used . . . 59 to encourage students to take the simulation class?

Question 20--Rank the following objectives as to . . 61 their importance to your simulation program.

Question 21--Is the Simulation class meeting the . . 66 objectives desired?

Question 22--Any additional comments would be . . . 66 greatly appreciated.

V PLAN OF IMPLEMENTATION . . . . . . . . . . . . 74

Introduction .............. . . 74

Objectives of Office Simulation . . . . . . . 74 
vii

CILAPTER

PAGE

Assessment of Student and Community Needs . . . . 75

Publicity.............. 76

Equipment .............. 77

Selection of Students ........... . 79

Implementation . . . . . . . . . 79

Review of Materials to be Used ......... 80

Rotation of Students .......... 86

Evaluation .............. . . 87

Course Evaluation

Student Evaluation

Instructional Materials .......... 88

Selection of Advisory Committee . . . . . . . 93

School Acceptance of the Office Simulation Program . . 94

VI SUARMRY, CONCLUSIONS, RECORRIENDATIONS . . . . . . 95

Summary ................ . . 95

Conclusions ............... . . 95

Recommendations .............. 98

BIBLIOGRAPHY . . . . . . . . . . . . 100

APPENDIX ................................ 105 


\section{LIST OF TABLES}

1 Length of Time Used for Simulation . . . . . . . . . . 39

2 Prerequisites of the Classes in which Simulation

is Taught ................. 40

3 Responses to the Block of Time the Classes of Simu-

lation Meet.................. 42

4 Texts or Materials used for Simulation . . . . . . . . 42

5 Business Equipment in use in Oregon Schools . . . . . . . 44

6 Rank of Criteria Used to Evaluate Simulation

Students by the Value Teachers Placed on

each Item (Al1 Classes in which Simulation

is Taught) ....................

7 Rank of Criteria Used to Evaluate Simulation

Students by the Value Teachers Placed on

each Item (Simulation Class) .......... 48

8 Length of Time Spent on Job Positions . . . . . . . . . 49

9 Credits Assigned to Simulation Class ........... 51

10 Credits Assigned to Classes in which Simulation

is Taught ................ . 52

11 Size of Oregon Schools in Relationship to Whether

or not Simulation is Taught and whether it is

a class or coordinated in other classes........ 
12 Class Size in Relationship to Size of School . . . . . . 54

13 Number of Independent Simulation Classes Taught and

Number of Students Enrolled in Classes in Relationship to the Size of the School ......... 55

14 Responses of all Simulation Teachers as to the Number

of Classes Taught and Number of Students Enrolled

in Classes in Relationship to the Size of the

School .................. 56

15 Leaming that Takes Place in Simulation that is not

Obtained Elsewhere ............... 57

16 Responses to Question 17: Why was the Program

Implemented in Your School? . . . . . . . . 58

17 Problems Encountered in Setting up the Simulation

Progran ................... 59

18 Promotional Methods used to Encourage Students to

Take the Simulation Class .. . . . . . . . . 60

19 Objectives Ranked as to Importance to Classes

offering Simulation .............. 64

20 Objectives Ranked as to Importance to the Independent

Simulation Class ............... 65

21 Responses to Question 21: Is the Simulation Class

Meeting the Objectives Desired . . . . . . . . 66 


\section{CHAPTER I}

\section{INTRODUCTION}

A primary goal of office educators is to provide relevant learning experiences that prepare the student for the world of work. Realistic learning situations can be provided in the classroom through a simulated office program.

At the present time, Reynolds High School does not offer a simulated office program. It was the desire of this writer to study the simulated office programs in the State of Oregon through a survey of simulated office teachers. The findings of this study were used to design a plan to implement a simulated office program in the Reynolds School District.

\section{Need for the Study}

A major objective of business education today is to provide relevancy in training for office occupations. After students have acquired the knowledges and skills necessary for employment, they should have the opportunity to apply these knowledges and skills.

The modern business office is rapidly changing and the demands on the workers are vigorous and diversified. Beginning workers tend to have the employable skills needed but fall short in qualities of good judgment, resourcefulness, and responsibility. These traits are also important in retaining the job and advancing in the positions within the company. 
Many businessmen suggest that renewed effort in teaching be made to develop within students preparing for offices the following:

1. The ability to handle oral and written instructions.

2. The ability to handle materials efficiently, to plan and organize work.

3. The ability to work under pressure with a minimum loss of time.

4. Versatility--the ability to adapt to changing work demands.

5. Responsibility-a sense of personal involvement in the success of the company $(35: 105)$

The business courses taught at Reynolds High School are not designed to incorporate the activities that would enhance the above mentioned ski11s.

At the time of this writing, the following business education courses were offered at Reynolds High School to meet the vocational and personal needs of the students:

Typewriting I

Personal Typewriting--1 semester

Intermediate Typewriting--(A remedial typewriting class for students not doing well the first year of Typewriting)

Business Communications--(Advanced Typewriting)

Career Office Education--(Office Practice)

Clerical Assistants--(Teacher aides)

Shorthand I

Shorthand II

Accounting I

Accounting II

Personal Finance 
Business Law

Briefhand--1 semester

Although Reynolds does not have an office simulation program, it does have a Diversified Occupations (work experience) program, which is not a part of the business education curriculum. There are many advantages to the work experience program. It does provide realism for beginning workers and does provide wages as well as school credit. However, this program at Reynolds has its limitations. It does not always place students in jobs relevant to their interests and training. Students are placed wherever jobs can be found with little regard as to their interests or abilities. It is not always easy to find enough cooperating businesses in which to place students. Work experience takes students away from school for a half day, thus preventing many students, who are interested in the extra-curricular activities and college preparatory classes offered by the school, from participating in this program. The program is limited to those students who have transportation to and from work. The location of Reynolds High School and the new Columbia High School makes it difficult for many students to leave school unless they have their own transportation. Work experience does not provide training for the student with limited skills and below-average ability. Some students are not ready for actual work experience. They need more training to develop their skills and the maturity vital to success on the job. For these students, a program within the school environment provides the best opportunity for this development.

The business curriculum at Reynolds also offers a career office education class (office practice), which includes a clerical assistant 
program. In the career office education class, advanced skills in typing and shorthand are developed and skills in business machines and filing are taught. The second hour of the class is a clerical assistant program whereby the students work in the office or for a teacher. The philosophy behind the clerical assistant program is to provide work experience for the students. However, in most cases, the experiences of the students are limited. Many of their experiences are confined to grading papers, typing tests on masters and using the duplicator.

A simulated office, in addition to the work experience program and career office education class, would increase the possibility of the students gaining realistic office training where they may obtain the traits suggested by businessmen.

The simulated office program would not replace any of the existing business classes. It would be taught in addition to the basic business classes and would be used as a capstone experience to help bridge the gap between the classroom and the business office. It would provide the student the opportunity to develop the personal qualities that are so essential to success on the job.

\section{Statement of the Problem}

The problem involved in this study was to ascertain the current methods and materials used by office simulation teachers in the secondary schools of the State of Oregon and to design a plan to implement a simulated office program in the Reynolds School District.

The questions to be answered were:

1. What are the prerequisites of the class?

2. For what block of time does the class meet? 
3. What text or materials are used?

4. What equipment is used?

5. How often are job positions rotated?

6. How are students selected for job positions?

7. What criteria are used in grading the students?

8. How many credits are given the students?

9. How many students are enrolled in the school?

10. How many students are enrolled in the class?

11. How many office simulation classes are offered?

12. Is the class integrated with other classes?

13. What learning takes place that students cannot get elsewhere?

14. Why was the program implemented in the school?

15. What are the objectives of office simulation?

16. Is the class meeting the objectives desired?

17. What problems were encountered in setting up the program?

13. What promotional methods are used to encourage students to take the class?

Purpose of the Study

The purpose of this study was to provide for the students in the Reynolds School District an office simulation program, which will teach them the office skills necessary to obtain employment, retain their employment, advance within the business, and to meet the challenges of the business world.

The Reynolds School District will have a new school, Columbia High School, opening in the fall of 1977 . There will not be seniors in the school until the fall of 1978. Therefore, the Fall of 1978 will be an 
ideal time to implement an office simulation program into the curriculum of the two schools.

The office practice teachers in Oregon were surveyed to determine what methods and materials are being used in those schools offering office simulation. The information obtained from the questionnaires was used to plan and implement an office simulation program in the two high schools in the Reynolds School District.

This study was written with the Reynolds schools in mind. Therefore, the availability of facilities, materials, equipment, and finances had an affect on the development of the program.

Chapter IV is devoted to the results of the questionnaires and Chapter $V$ is the plan of implementation of the office simulation program for the Reynolds schools.

\section{Delimitations}

This study was limited to the 170 schools in Oregon which offer some type of office practice class. The study was conducted during the months of March through June 10, 1977.

The data utilized in this study was obtained from secondary office practice teachers in Oregon, who responded to the questionnaires. The data received was limited to the checklist questions asked by the writer of this study.

The questionnaire was designed basically to gather information about materials and teaching methods used by office simulation teachers.

Additional data from related literature was used by the writer of this study to develop the plan of implementation of a simulated office in the Reynolds School District. 


\section{Definition of Terms}

Advisory committee: A group of businesspersons and others in the community, who are interested in the welfare and advancement of business education in the school. The committee's functions are to help secure proper training stations, recommend curriculum changes, recommend minimum standards, assist in community surveys, assist in job placement after graduation, and suggest and help secure resource speakers.

Blocked time: Students are scheduled into the same classroom, usually with the same teacher for two or more consecutive periods daily.

In-basket Project: A simulation of actual office input but does not provide for interaction among workers.

Integrated Project: A unit of simulation in which only a portion of the office workers' duties are simulated.

Model Office: An area within the confines of the school building where facilities and equipment are organized in such a way that they assume the appearance of a real office operation. $(25: 7)$

Office Practice: A class in which students become familiar. with office machines, refine previously learned skills, and develop desirable office traits.

Simulated office: A course held in the model office where students conduct themselves as office employees of a simulated company while learning necessary skills, procedures, and attitudes. This is done by providing students with realistic, simulated assignments and projects which require cooperative efforts and use the standards of the office as criteria of achievement. (47:10) 
Vocational Education: That part of the school curriculum which teaches the skills and knowledges necessary to obtain and retain employment, which is necessary for the economic security of the worker. Work flow: No two people are doing the same job at the same time. The work of one person depends upon the work of another.

Sumnary

The information obtained from the questionnaire completed by the office simulation teachers of Oregon was used to determine the methods and materials to be used in the simulated office program in the Reynolds School District. Related literature was also used as a source of information in devising the plan of implementation.

Having a simulated office will increase the opportunities of business students to gain relevant office training, which will further develop their skills and business traits which are vital to success in the business world. 


\section{CIIAPTER II}

\section{REVIEW OF RELATED LITERATURE}

To provide a background of office simulation, literature relevant to this topic was reviewed. The general areas the writer covered include the history of simulation, its purposes and objectives, preparations needed for developing and running the program, and its advantages and disadvantages.

\section{History of Simulation}

For many years, the preparation of students for office work consisted of classes in typing, shorthand, and bookkeeping in a business school. As more and more office jobs became available and employers became more demanding in their requirements of job applicants, business educators began to realize that the student needed more to prepare for the job than the basic skills learned in school. The need for relevancy of the training to the world of work became evident. This brought about the beginning of office practice classes in the early 1900's. The biggest concern of the educators was to train their students for entrylevel positions.

In 1927 a study was made of office managers which determined that interpersonal relations training was an important factor in training office workers. During the years that followed, the professional literature was full of articles urging teachers to develop instructional 
programs that would simulate job conditions. $(36: 104)$ The public schools integrated the business curriculum in the 1940's. Gradually, classes such as general business, business arithmetic, office machines, and office practice became part of the curriculum. The movement toward office simulation had begun.

In 1947, an issue and services editor of the UBEA Forum ran a series of articles entitled "Office Standards and Cooperation with Business Service." In these articles, he asked business educators and businessmen to write articles concerning office standards and the relationship between the school and business. This initiated the publication of articles on the relevancy of business subjects taught.

In the 1950 's the model office began to emerge. Very few materials were available for teachers, so they began by developing their own programs and materials. They began writing about their experiences and publishing them in business education magazines. More and more educators recognized the need for the simulated office.

In 1963 the passage of the Vocational Education Act and the Amendments of 1968 brought about large amounts of federal funds to maintain, extend, and improve vocational education. Many new programs developed from this act. According to Poland (40:29), new programs in simulation and block-time instruction have been developed as a solution to the problem of educating youth for today and tomorrow's office careers. The act specifically suggested the development of total programs for preparing youth for the world of work. Specific but isolated courses are no longer considered to be the core of office education but a total office program centered around the needs of individuals was determined necessary in the legislation. 
Besides the simulated office programs, other programs such as integrated projects, work experience, cooperative work experience and simulated work experience developed from the Act.

Many states chose to provide money to start programs in cooperative education. This was to be the ideal training situation. However, many of these programs did not provide the training needed for office workers. It was difficult to find the right kind of stations; the training provided was inadequate; or there simply were not enough training stations. The students were not properly supervised, and it was difficult to evaluate them. Problems existed within the school in scheduling the students and with teachers who were reluctant to dismiss students for work.

Some states took a second look at the program and decided to encourage office simulation in schools where it was feasible. Through the State Department of Education, workshops were held and programs were developed.

By the 1970's the program was well on its way. In 1972, Condor and Rainey $(13: 45)$ conducted a survey of office practice teachers of the Mountain-Plains Business Education Association and of Arizona, Arkansas, Missouri, Louisiana, and Montana. Of the 454 teachers responding, 68.3 percent stated that students taking office practice received simulated office experience as part of classroom instruction.

The popularity of the simulated office is high. It is now a college offering, an often scheduled workshop, a part of institutes, and a topic of association meetings. It is easy to find articles devoted to office simulation in the trade magazines and yearbooks.

Businesses have recognized the importance of simulation training in the clerical curriculum and have offered assistance in developing programs. The Washington Insurance Council, for example, has developed a 
Homeowners Insurance simulation and offers free materials to schools. Instructional publishers have developed materials so that there are now commercially prepared simulation materials available. Teachers have developed their own simulation packages. Simulation has become an accepted method of bringing about relevancy in office education.

Simulation Defined

Simulation is not new to education. It has been around for many years in non-public education. It has been used for years in aviation training, driver training, and astronaut training. It has been used in the military, in industry, and more recently in government. It is also "not a new approach in business education; however, this plan does provide for a renewed emphasis where jobs and tasks are performed by students in a well-planned environment." (10:32)

Many definitions of office simulation are offered in the related literature. Elaine Uthe described it this way: "Simulated office is used to refer to 'realistic experience'--particularly the type of realism that is achieved through office-like settings, office-like production jobs, and office-like positions." (56:141)

According to Hansen and Parker $(21: 226)$

It is a real organization of students formed under the direction of the teacher that carries on integrated office functions at a level of intensity and in a facility which corresponds very closely to those of a typical business office. In reality, a simulated office could be carrying on the work of a real business concern.

Other writers, in offering definitions, repeatedly used such terms as realistic learning, relevancy, reality, integration, total involvement, work flow, and individualized instruction. 
Purposes of Simulation

There has always been a gap between the classroom and the business office. It is the purpose of office simulation to "bridge the gap" in order to make it easier for the student to adjust to the office situations of the first job. For many years, employers have expressed a need for students "to understand job relationships and see how each individual's job fits into the total office operation." Students have suggested that a class be offered in their senior year to "put it all together" so that they could apply their skills to a realistic situation and be evaluated on the effectiveness of those skills. (45:12)

When the student makes the transition from the classroom to the business environment, he should have entry level skills, developmental skills, and maturity. (32:161) Simulation provides the link necessary to make the transition as smooth as possible.

Some students who have had work experience say that many of the tasks they are expected to perform on the job are not the same as those taught in the school and that the material learned in school is not consistent with the demands of the job. (42:5) Students need to know how they will be expected to perform on the job. According to Poland, $(39: 265)$

If they are taught the necessary skills and are acquainted with the necessary terminology, but have no knowledge of how to coordinate the skills, they will have difficulty in applying school-taught skills to on-the-job demands.

Realism is the factor that makes simulation an important part of the office education program. It provides a realistic experience for each student in the program. Several writers feel that the student who has had the experience of simulation has an advantage over the student 
who has not had simulation. They feel it provides the student with additional skills that are lacking in the non-simulation student.

One of the primary purposes of simulation is to develop the student's dependability, promptness, initiative, pride, and other attitudes which will help to maintain good relationships with others. In 1966, Charles $R$. DeCar1o, Director of Automation Research at IBM, stated that attitudes on the job are more important than other skills. He noted that skills are necessary to achieve adequate standards, but attitudes are important in advancement and promotion within the firm. $(55: 13)$

Wunsch (60:7) felt that businesses demand that employees have not only the necessary skills for the job, but also the necessary ability to cooperate and interact effectively with fellow employees.

Lea (29:55) surveyed the personnel directors of 11 industries in the San Jose metropolitan area. These employers felt that workers who have experience in working with people make the best workers. They suggested that working in a simulated office classroom would be helpful.

There are some skills, such as assuming responsibilities for completeness and correctness of work done, and meeting deadlines, that are learned only by working with others. As stated by Hansen and Parker $(21: 226)$, "Simulation is group learning." The primary relationships are among the people in the group. They learn to work together successfully. The group must act together as a team to perform the tasks. According to Smith (51:56), business is not simply "machines, figures, and inanimate objects. Business is dealing with people."

Office simulation gives students the opportunity to get the feeling of a "live office." It gives them the opportunity to see the whole picture. 
The interaction that takes place in the actual business can be duplicated in the classroom. It, therefore, gives students the benefit of paper flow and job dependencies encountered in any business organization. (14:4)

The purpose of office simulation is to make the transition from school to work as smooth as possible. Simulation is based on the premise that skills, attitudes, and knowledges learned in one situation will tend to reassert themselves when the elements of the learning situation occur again. $(39: 265)$

\section{Objectives of Simulation}

In a survey of office practice teachers conducted by Condor and Rainey (13:45) in the NBEA Mountain Plains region, it was found that 59.1 percent of 257 responding teachers rated the main objective of office practice as "the development of those acceptable character and personality traits and work habits needed in the business office." Second in importance was "building a background knowledge of business principles, office organization, and occupational information." Third in importance was "to improve and coordinate office skills learned in other courses."

Ringersen (44:22) listed her model office objectives as follows:

1. To provide situations in which students are required to integrate previously learned knowledges and skills.

2. To provide for the application of these previously learned knowledges and skills in a demanding work situation.

3. To establish situations requiring that students work cooperatively with others in completing assigned tasks.

4. To provide situations requiring the student to evaluate the situation, call upon previously learned knowledges, acquire new knowledges needed for solving the problems, finally make a decision, and later evaluate the decision in terms of the result. 
In on-the-job observations conducted by prospective business teachers at Radford College, one executive secretary in the study advised that business classes should attempt to develop in future employees:

1. Effectiveness in getting along with others.

2. Ability to work independently.

3. Loyalty, integrity, and discretion.

4. Capacity and willingness to accept responsibility.

5. Judgment, initiative, and resourcefulness.

6. Poise. $(49: 10)$

Fritz (16:57) listed the following objectives:

1. To provide terminal vocational training for stenographers, clerical, and bookkeeping students.

2. To acquaint students with business standards and requirements.

3. To help students develop an awareness of the responsibility inherent to an office position.

4. To help students develop desirable work habits such as ability to organize, to follow directions, and to be thorough and efficient.

5. To help students develop desirable attitudes, ideals, and traits of character.

6. To provide opportunity for students to develop the ability to evaluate their work and the work of others.

7. To provide further development of personal qualities essential to be an effective member of society and for success as a business employee.

\section{Simulation Prerequisites}

A simulation program requires much time and preparation on the part of the instructor. Before implementing an office simulation course in the secondary school, the community should be surveyed to find the needs, scope, and nature of the businesses. Fruehling (17:17) said that the program needs to be built on "manpower needs" by

1. surveying the community for number and extent of office jobs.

2. assessing the skills and knowledges required for each job cluster.

3. determining which job could best be served by the office occupation program.

4. developing individual training programs to accomplish these job goals.

5. recruiting appropriate students for the training program. 
Student needs shouid also be considered. Sawaia (47:10-11) listed

four kinds of student needs that should be considered in the simulated laboratory:

1. Initial learnings

2. Advanced development of prior skills

3. Application (task practice)

4. Simulation

In setting up the program, the simulation must; according to Krawitz $(26: 7)$

1. resemble a real office, where there are no artificial standards to meet, where performance itself counts.

2. provide the broadest possible range of office experience, so that each student can make an easy transition later on to a variety of office jobs in the real world.

3. permit a realistic flow of work from station to station and a realistic set of routines and procedures.

4. contain the checks and balances that are found in a real office.

5. challenge the students on a personal basis.

Wunsch $(60: 7)$ thought that simulation

1. should be realistic.

2. should meet the particular job needs of the students served.

3. activities should be interesting to the student.

4. should be developed to meet specific objectives.

5. student manuals should be prepared.

6. evaluation of employees should be conducted regularly.

7. students should complete job applications and personal interviews with the instructor.

8. should be conducted for concentrated periods of time.

According to Sabin $(46: 5)$, in setting up the simulation program, simulation should simulate the

1. way input comes in on the job.

2. conditions under which the student will be expected to perform on the job.

3. standards of quality and quantity by which the work would be judged on the job.

Comprehensive business courses are still a vital part of the business curriculum and to the simulation program. They are the backbone of the 
office education program and are a definite prerequisite for the student who enters the simulation program. The business education students at Radford College who made the on-the-job observations of business offices found that typewriting was still a basic requirement for every job and shorthand for some of the jobs, but that proficiency in these skills alone was insufficient preparation for the job. (49)

In preparing for the simulation program, it would be well for business teachers to get out into the world of business, visit a company, and find out what is expected of the beginner worker. They should observe employees on the job. The teacher must, however, spend enough time in observation to see the complexity of a job and its numerous elements. Business forms should be collected and the flow of work should be analyzed. When Krevolin $(27: 6)$ was searching for an office to simulate on-the-job training for typists, he searched for a model that would help him "(1) get details about tasks performed, (2) obtain sample forms, supplies, and stationery, and (3) evaluate the attitudes of people about the jobs they perform."

\section{Examples of Simulation Projects}

Simulation can range from units in textbooks or workbooks to a fullscaled model office. Many office education facilities are elaborately furnished while many others have the bare minimum. The success of the program does not depend on the facilities but on the objectives of what is to be accomplished. A wide variety of simulated offices are in existence throughout the country. They range from small units prepared by teachers to large commercial packages designed for the full-year, blockedtime course. 
Christian (7) held an office visitation project in his office practice class. Students spent a day in a local business office. A number of different offices were visited so that students would be placed in an office that fit their interests. They experienced first-hand what an office employee is expected to do. Schatz (48) simulated business problems in her office machines class and used time cards for the students to check in and out of class.

In a more complex program, Ahlgren (1) combined four courses (advanced typing, advanced shorthand, beginning office machines, and advanced office machines) for a lab. Four vocational business teachers coordinated the operation of the $1 \mathrm{ab}$ and had the responsibility for certain students. The lab was run like an actual office and put the responsibility on the student for getting work completed and turned in on time. Quigley (43) also combined several courses into one which was called office procedures. Three teachers acted as "department heads" of a secretarial pool, typing pool, and accounting department. Each student was assigned a different department each day and was given the assignment when clocked in.

Some simulation classes offer services to the school and community. In Sister Marie Angela's (2) class, the students did "real" office work for the school. The class compiled and sold booklets, Canada's 100th Birthday, which gave them experience on the principles of running a business. Kroeger's (28) office practice class also offered a typing service to the entire school. All work done was logged in a Mimeo log book or a Ditto $\log$ book. Clerical aides were assigned to department offices, attendance office, nurse's office, and teachers who needed clerical assistance. 
In a more elaborate set up, a Vocational Center for secretarial training in a Las Vegas, Nevada school was "organized and equipped to. provide up-to-date, individualized, in-depth training" with the latest equipment. It was also made available to adults from the community, which added a stabilizing influence to the class. (37) In Utah, a Mobile Office Education unit consisting of two 36-foot trailer houses connected together traveled among four school districts. The unit was furnished with upto-date, authentic office equipment. Students were taught the necessary skills in the classroom and then given the opportunity to use them in the "office" when the unit arrived at their school. (22) Drenth (15) had an elaborate simulated office with color-coordinated office furniture. Partitions set aside a private office for each executive. Students came from eight high schools and were interviewed for entrance. Sixteen work stations were available with eight different types of jobs. Students who took the course during the previous year occupied 15 other stations, which were promotional, supervisory, and administrative in nature. Weekly paychecks were given for the value of work done. Only perfect work received credit for production. The teacher was the president of the firm.

Neal (38) described three forms of office simulation:

1. The model office, which is based on real operations, contains work stations and office organization, and involves a flow of work.

2. The in-basket project, which does not provide for interaction, but does simulate actual office input.

3. Role playing, case problems, or critical incidents.

Poland (41:23) suggested four office practice models which include simulation:

1. The traditional class with case studies, in-baskets, class projects, etc., through which the student would develop the decision-making processes. 
2. A simulated office block program with two traditional classes blocked with integrated exercises and projects.

3. A simulated office block program with two traditional classes blocked with integrated exercises and projects and adding a model office simulation at the end of the first semester or whenever the teacher desires.

4. A basic review at the beginning of the year and model office the remainder of the year.

\section{Teacher Responsibility}

Some teachers have no problem fitting simulation into their programs, while others experience much difficulty. There seems to be no real explanation of this. What works for one teacher does not always work for others. Working under different conditions, with different people, and with different materials has an affect on the difficulty of initiating the program. The teacher needed for this type of program is one who is willing to innovate. The success of the program is going to depend on the "innovation, knowledge, skill, and methodology of the individual teacher." (8:190)

The office simulation teacher must be willing to deviate from the structured classroom. Simulation requires a "relaxed atmosphere" and students need to be "treated as adults" and allowed "responsibility for their own actions." $(18: 22)$

In order to have a successful office simulation program, the teacher must learn from the businessman what qualifications and skills they expect from office workers. The best preparation a teacher can get is to go out into the business field and get current, practical experience. Wingo (58:12) expressed her feelings in the following paragraph:

There is a need for institutes, workshops, and time away from classes for designing, experimenting with, and evaluating simulation experiences. Most important, it is necessary that business teachers expose themselves to office experience, for it can be difficult to plan office conditions as they really exist if office life is not familiar. 
Hanson and Parker $(21: 237)$ outlined the characteristics of a successful simulation teacher.

1. Recent on-the-job office experience.

2. A good working relationship with the school administration.

3. Constant contact with business people.

4. An active advisory council.

5. A desire to teach with new methods.

6. The common sense and abilities of an office manager.

7. A good simulation package.

8. Constant interaction with other simulation teachers.

9. Professional assistance from university and state office education personnel.

Methods of Teaching Simulation

Alvin Toffler criticized American education as regimentation, rigid seating arrangements, mass instruction, emphasis on grading, authoritarian teachers. These comments are not found in a good simulation program. "With simulation, the student is both. learner and teacher, doer and critic, listener and speaker." (34:156) The "subject-oriented approach" is no longer sufficient. Students want experiences that are meaningful. The "job-centered approach" is of utmost importance. As stated by Fruehling $(17: 17)$

It equips the potential employee not only with the manipulative skills needed to fill the technical requirements of the job but also with the abilities needed to adjust to the work environment and, thus, find a satisfying role in life.

An authentic simulation should exhibit three characteristics no matter what may be the objectives. It should simulate the

1. way input comes in on the job.

2. conditions under which the student will be expected to perform on the job.

3. standards of quality and quantity by which his work would be judged on the job $(46: 5)$

It is important for the teacher to consider the following points when using a simulated program: 
1. Be realistic--simulate a real business, not what a business presumably does.

2. While planning and preparing the simulation, focus attention on the objectives you have listed.

3. Remain flexible enough to improve the simulation at any time.

4. Remember to give the student encouragement.

5. Constantly keep alert for revision and improvement of the simulation. $(4: 260-261)$

A meaningful career preparation program must represent a cooperative effort between education, business, and government. This long-term commitment toward change must be directed to:

1. Supplying the students with necessary entry-level skills to meet employers needs.

2. Attracting increasing numbers of qualified students into business education and careers in business.

3. Strengthening the instructional staff and improving the quality of teaching.

4. Providing the needed support for the development of long-range programs in business education. (32:187)

The challenge to business educators today is

to equip students for a multiplicity of office occupations;

to teach more, teach it better, and teach it in less time;

and finally to instill in your students the willingness to tackle a new job with confidence, initiative, and know-how. $(11: 7)$

Time

There are conflicting philosophies about the amount of time that should be spent on office simulation. There are two aspects of time to be considered; the block of time used each day and the length of time over which the course will run. Simulation

may run from 30 to 40 hours to over 500 hours. The number of employees and the skills and knowledges they bring to the office will, in large measure, determine the complexity of the operation and the length of time most desirable. Many teachers have found one semester of a two-hour time block to be adequate for their students. $(34: 151)$ 
Evidence also indicates that the longer the time allotment for the simulation instruction, the more transfer will take place. Therefore, the rationale for block-time instruction. Offices, naturally, operate on longer time schedules than the traditional one-hour office practice class period offers. $(41: 269)$ Thomas $(54: 145)$ felt that "through a two- or three-period block of time, more effective instruction could be provided to build advanced skills, while, at the same time, integrating realistic practice through a simulated environment similar to that found in the modern business office." According to Lightner (31:96), "the basic assumption of the block-time simulation approach is that it is a more effective approach than the traditional single-period method."

On the other end of the spectrum, Snell (52:39) warned that "when class periods are extended into two- or three-hour blocks of time, the possibility of wasted time and non-productive activities exists." There is also "the ever-present danger of monotony unless interesting subjectmatter units are developed, unless activities are well planned, and unless varied instructional methods are employed." Hosler (23:10) felt that "simulation programs make their greatest contribution to the business curriculum when used as a 'capping' activity of four to six weeks in length in the clerical practice and/or the stenographic capstone courses."

\section{Developing a Simulated Office}

In order for the students to obtain the desired outcome from office simulation, it "should be relevant, realistic, and meaningful for students at every ability level, and materials should be designed so that all teachers could use them, beginners as well as the more experienced." $(9: 20)$ 
Literature has offered several guidelines for the teacher to follow in setting up a simulated program that will closely resemble the "real thing." Dr. Wingo (58) felt there are some explicit rules in designing office simulation that must be employed if the experiences are to be as close as possible to that of real office situations.

First, performance objectives must be identified so that all of the appropriate elements and relationships can be blended together to accomplish the objectives for the particular office situation.

Second, a model of the office situation must be constructed in a manner that facilitates serving the stated objectives. Selections must be made of those office tasks and behavior that are common to most offices so that particularly important aspects of office life can be brought to the foreground, highlighted, and clarified.

Third, the various personalities and work objectives of each office worker must be described. The job of each office worker should be designed in such a manner that it impinges on the work of others in the office and is in some way dependent upon consultation and direction from outside the office. In addition, there must be programmed into the simulation a certain amount of pressure, interruption, and irritation if the experience is to be representative of office conditions.

Finally, the stage must be set and the novice office workers must be instructed for the beginning of the simulated experiences.

Gentzel $(20: 106)$ listed the steps which he feels are necessary for the successful development of a simulated program.

1. Survey the business offices in the community and decide on a theoretical business.

2. Establish objectives for the program.

3. Based on the objectives of the theoretical business, the physical facilities of the school, and the needs of the students, develop individual work stations.

4. Prepare job descriptions for each station, relating the functions of each to the others and to the business.

5. Establish a flow of work.

6. Prepare job instruction manuals for step-by-step work performance for each station. 
7. Prepare a contingency list of activities to vary or interrupt the daily routine.

8. Develop a method of evaluating student performance.

Ringersen (44:23) listed the following procedures to follow in develop-

ing a model office:

1. Collect raw data from the world of work.

2. Convert the data into forms which are usable and realistic to the student.

3. Develop job positions essential to the functioning of the model.

4. Define the basic functions for each position.

5. Define the routine basic for each position.

6. Prepare a flow chart to portray relationships of jobs.

7. Prepare a job description and a job manual for each position.

8. Prepare a company manual giving background, setting, and general procedures.

Lightner (31:98) suggested an outline for teachers to follow in developing simulated materials.

1. Introduction

2. General objectives of the simulated.approach.

3. Behavorial objectives

4. List of the component parts to be integrated

5. Prerequisites or background of students coming into the simulation

6. Flow chart of the task, job, or model office

7. Layout sketch of facility with the equipment necessary and supplies necessary

8. Forms to be used in simulation

9. Detailed description of procedures to follow in carrying out the simulation. This could be the directions for the students or information necessary for the teacher.

10. Method of evaluation for the project upon completion

Barger $(4: 261)$ offered the following plan:

I. Planning--Teacher

A. Determine the objectives you plan to accomplish through simulated office operation.

B. Determine what you will simulate

1. Collect data necessary for planning simulation

2. Define limits of simulation

3. Define systems process of simulation

C. Determine the guidelines and requirements

1. Time

2. Space

3. Equipment

4. Supplies 
5. Facilities

6. Evaluation

7. Funds

8. Forns

9. Placement of Equipment

10. Number of students

D. Select basic routines

1. Define basic routine

2. Prepare job description manuals

E. Prepare forms

F. Prepare transactions

G. Prepare a basic script

H. Prepare a contingency list (a list of items for each position which you may use to adjust the workload of that position)

I. Establish grading procedures

II. Orientation--Student

III. Positional training--Student

IV. Simulation Warm-Up or Tryout--Student

V. Full-scale simulation

VI. Debriefing--Student

A. Class discussions

B. Adjustments

C. Summarization

Sabin (46:5) stated that an authentic simulation should exhibit these characteristics:

1. It should simulate the way input comes in on the job. It should be provided in a realistic variety of written and oral forms and in a realistically unorganized fashion.

2. It should simulate the conditions under which the student will be expected to perform on the job. It should replicate the work flow and the procedures and make available the kinds of records, reference materials, files, and other resources the student would find on the job.

3. It should simulate the standards of quality and quantity by which his work would be judged on the job.

Equipment

Depending upon the finances and resources available, the simulated office equipment will range from the very up-to-date, modern equipment 
to the very minimum outdated equipment. Effective simulation can still take place even with old equipment. However, "an earnest effort must be made to keep the newest type of equipment. There is nothing more discouraging for a beginning worker than to enter the business world and find that he has been trained on antiquated equipment." (59:18) The equipment should be up to date and relevant to the business office. "Office machines and related equipment should be placed in the office practice classroom on the basis of their use frequency in the business office." (11:4) There should be as much variety as possible in the selection of equipment and machines and the most instruction time should be spent on the equipment most used by businesses in the community.

The arrangement of the classroom equipment should resemble as closely as possible a business office. It should in no way resemble the typical classroom.

\section{Evaluation of Students}

When checking the work of the simulation student, the evaluation should be based more on the quality of the work than on the quantity. The goal should be mailability of the materials. Standards of mailability differ from teacher to teacher and also from employer to employer. The student must be made aware of this and conditioned to accept the fact that he must please his supervisor, whoever he may be. (6:3) The evaluation should be done "according to the number and the quality of the performance goals they have met." $(42: 29)$

Funk $(20: 31)$ said that evaluation of students in simulation is no real task, for they are evaluated as though they were on the job. The same criteria is applied in grading them as their employers will apply to 
them on the job. Attendance, attitudes, productivity, accuracy, ability to work well with their co-workers, ability to come to the room and get right to work, etc. are closely observed. Students know these criteria will be applied from the first day of the simulation, and they also know that they must call in to their instructor any morning they will be absent. Hanson and Parker $(21: 230)$ suggested the following ways of handling evaluation:

1. Have the students make a carbon copy of all typewritten work they complete. Place their copies in the out basket on their desk to be picked up and placed in a file. Each student will have his individual file so that the teacher can periodically check the amount and quality of work performed.

2. Have the student office supervisor periodically evaluate every worker under his supervision. These evaluations should be personally handed to the instructor and kept confidential. With some teacher assistance, the students can be very objective. The teacher should evaluate the supervisor each time the supervisor evaluates his workers.

3. Periodic efficiency checks can be made on performance goals through the use of a timed production quiz. An example of a typewriting quiz would be a series of letters that have to be completed in a set period of time. Interrupt the student with such controlled intrusions as telephone calls, visitors, and other office business so that he can be evaluated under pressure. Establish norms and evaluate his work.

Lynn (33:25) used a payroll in her evaluations.

Employees receive and deposit their paychecks twice a month. Superior performance is rewarded through pay raises, and through promotions. Grades are based on these five factors, which are measured from available data: (1) dependability, (2) cooperation (3) knowledge of job, (4) quality of work, and (5) quantity of work.

Advantages and Disadvantages of Simulation

Various authors have given the following advantages of an office simulation program:

1. Simulation sets the stage so that students, through application of knowledges and skills previously learned, can cultivate many desirable characteristics and attitudes toward work. (5:15) 
2. The many problem-solving situations presented through the office simulation scripts, as well as the performance of ordinary dayto-day office operation, challenge students to develop tact, in addition to accomplishing the task; be objective regarding their work and interpersonal relationships; accept failure and success gracefully; work effectively with fellow employees; work with a supervisor; organize detailed work; and develop self-confidence. $(5: 15)$

3. Mistakes can be made without serious detrimental consequences in a simulation experience; reality can be reduced in size until it becomes manageable; and by including only the salient aspects of a particular situation, clarity can be brought out of what would otherwise be complex and confusing $(58: 12)$

4. A wide range of office activities can be covered. $(34: 152)$

5. Fast Feedback-Within a simulation, one can shorten the time factor so that the student can quickly see the consequences of his actions and can repeat the action if necessary or revise the action or take new action on the basis of the feedback he gets. The consequences may be realized the same day or at the most the next day. $(46: 6)$

6. Control factor--The peripheral elements or complex variables that exist on the job but could distract students or discourage them during this phase of their training can be removed. As they develop competence and confidence, the teacher can introduce additional variables to provide them new kinds of occupational experience and give them the opportunity to demonstrate higher-level mastery of the job. (46:6)

7. Low-risk factor--The consequences of failure can be minimized. A student who makes a botch of a transaction is not going to cost a real company any financial loss or any serious human relations problem. He may feel freer to reach out for more complex responsibilities, knowing that an initial failure is not going to cost him his job or his own self-esteem. (46:6)

8. Cost factor--More students can be accommodated at less expense than is typically entailed in on-the-job training. (46:6)

9. Simulation instruction can be highly individualized. (31:98)

10. Simulation is realistic. (31:98)

11. Simulation is not boring. $(31: 98)$

12. Simulation is self-revealing. (31:98)

13. Simulation helps to meet the problem of transference of knowledges and skills. (31:98) 
Some of the disadvantages noted are as follows:

1. Lack of interest of some students. (50)

2. Not enough time to learn all jobs. (50)

3. Not enough time at each job. (50)

4. The time required to properly conduct or set up the simulation. $(53: 22)$

5. All the variables and information cannot be included or total realism captured. $(53: 22)$

6. There is far too much emphasis on the "interaction" of students in "playing office." Such long prograns of simulation rob the student of time needed to develop through regular courses the clerical or stenographic skills and knowledges needed to perform well in the office of the real world. $(52: 39)$

7. Instructional materials are not developed. $(54: 148)$

8. Teachers are not appropriately prepared. $(54: 148)$

9. Takes too much teacher preparation time. $(54: 148)$

10. Scheduling difficulties $(54: 148)$

11. Absenteeism that causes an interruption or cessation of the work flow can cause irreparable harm. $(3: 10)$

12. Careless work habits results in an intolerable amount of unnecessary expenses. $(3: 10)$

13. Each worker must be alert to double check part or all of the work that has been done before as he performs his appointed task. $(3: 10)$

Sunnary

Because of the demands of business, business educators have found it necessary to better train students to enter the business office with entrylevel skills. These demands have brought about the office simulation program. Office simulation ranges from a unit from a textbook to a 10-hour per week simulated office which allows the student to work with materials, work flow, equipment, etc. relative to an actual business office. 
The teacher plays a big part in the simulation program. Much time and effort is required in the planning and organizing of the materials for the office situation.

The basic office skills are learned before the student enters the simulation program. The simulated office program concentrates more on developing character traits in the student such as attitudes, initiative, cooperation, ability to work well with other workers, being able to accept criticism and failure, etc. than it does on the basic business skills.

In most cases, it is recommended that block time be used for the simulated office. However, some educators feel that block time wastes too much of the student's time when other skills should be learned.

In order for the simulated office to be effective, it is not necessary for the classroom to be equipped with new expensive equipment. However, the equipment should be a type similar to what would be found in the real business office.

It is important that the teacher surveys the community to find the types of jobs into which the students will be going. If at all possible, the teacher should gain practical, on-the-job training to be more aware of the situations the students will be facing.

The evaluation of the students is going to depend on the quality and quantity of their work, upon their attitudes, and adaptability to their job.

Simulation offers many advantages to the business student, but it also has its drawbacks. However, the advantages tend to outweigh the disadvantages. 
CHAPTER III

METHODS AND PROCEDURES

\section{Introduction}

In this study, office practice teachers in Oregon were surveyed and related literature was reviewed in order to gain ideas for planning a simulated office program suitable to the facilities available in the Reynolds School District. The 170 Oregon schools surveyed all had an office practice class of some type.

$\underline{\text { Research Technique }}$

The names of the secondary schools surveyed were obtained from the files of the Career Cluster Office of the State Department of Education in Salem, Oregon. Some course titles of the office practice classes taught in the schools selected for this study are as follows: simulation, model office, block, office practice, clerical lab, office procedures, clerical practice, office occupations laboratory, and clerical pool.

A questionnaire and cover letter were sent on March 28 to each of the 170 schools in Oregon which listed some form of office practice in their curriculum. A self-addressed, stamped envelope was enclosed with the questionnaire.

To develop a plan of implementation of a simulated office program in the Reynolds High School, literature relevant to office simulation was reviewed in addition to the findings of the questionnaire to gain 
ideas and materials for implenenting the program. Several different commercially prepared materials were previewed before the investigator decided on the materials to be used.

\section{Refinement of Instruments}

The questionnaire designed by the investigator was distributed to five office simulation teachers in the Portland area schools. The teachers were asked to fill out the questionnaire for their office simulation class, and to evaluate the questionnaire as to completeness, ease in completing, and clarity of questions. They were asked to return the questionnaire and their comments to the investigator of this study.

The questionnaire was also submitted to the Tests and Measurements class at Portland State University for an evaluation. Suggestions for improvement were made by both groups, and the questionnaire was changed. It was then submitted to five additional teachers in the Portland area schools for evaluation. The questionnaires were returned with no further comments or suggestions, so the questionnaire was considered valid for submitting to the office practice teachers of Dregon.

\section{Selection of the Population}

A list of the secondary schools in Oregon which offer office practice classes was obtained from the Career Education office of the State Department of Education. In order to get a variety of responses, all 170 schools with office practice classes were surveyed.

\section{Follow-up}

On May 2, the same questionnaire with a new cover letter was sent to all schools which had not responded to the first questionnaire. The deadline to return the second questionnaire was June 10. 
Treatment of the Data

The data received on the questionnaires returned were analyzed and illustrated in tables in Chapter IV.

The data were analyzed according to two classifications--the responses from all teachers who teach office simulation, and from those who teach a class of simulation independent of other classes.

The percentages shown in the tables have been rounded to the nearest whole number.

The data received and literature related to office simulation were used to design a program to be implemented in the Reynolds School District. The plan of implementation is presented in Chapter V.

Summary

One hundred and seventy secondary schools in Oregon who offered some form of office practice class were surveyed. A refined questionnaire and cover letter were sent to each participating school. A second questionnaire was sent to any school that had not responded by Hay 1.

On June 10 , compilation of the data received began. The data obtained from the questionnaire and related literature was used to suggest a plan of implementation of a simulated office in the Reynolds School system.

A summary of the data received was mailed to all participating schools who requested it. 
CHAPTER IV

PRESENTATION OF THE FINDINGS

One hundred and fifty-six of the one hundred and seventy (ninetytwo per cent) office practice teachers in the secondary schools of Oregon returned the questionnaire. One questionnaire was returned in unuseable form. The findings of the study will be presented in this chapter.

The following format will be used to present the findings. Each question is numbered as it appears in the questionnaire. The question is used as a sideheading and is followed by an analysis of the responses to that question. The responses have been analyzed according to (1) all schools which offer simulation as part of their business curriculum and (2) only the schools offering a separate simulation class. Hereafter, this class will be referred to as simulation class.

Question 1--Do you have any form of office simulation in your business curriculum?

From those responding to the questionnaire, more teachers offer some type of sinulation in their business classes than do not. One hundred and two teachers reported some type of office simulation in their business curriculum. This represents 65 per cent of the teachers returning the questionnaire. Fifty-four teachers responded, "no," to this question, or thirty-five per cent of the teachers returning the questionnaire. Since one of the 102 questionnaires answering in the affirmative was unuseable, 101 responses will be used in figuring the percentages in the tables. 
Question 2--Name of simulation class.

Many different titles are used by the Oregon teachers for the course the author refers to as office simulation. Twenty-two different course titles were used by forty-five teachers for the office simulation class. Below are listed the office simulation course titles and the number of teachers reporting them.

\section{Course Title}

Office Simulation

Model Office

Office Practice

Office Procedures

Lester Hill

Steno Cluster

Clerical Cluster

Legal Secretarial Magnet

Simulation

Simulated Office

Business Office Procedures Services

Office Power

Apex Model Office

Bookkeeping \& Business Machines Cluster

Office Management

Office Block

Business Occupations Skills Center

Random Hill Publishing Company

Pirate Insurance Company

Lester Hill Simulated Office

Student Secretarial Service

Business II

No response
No. Reporting

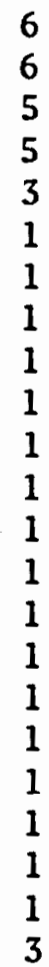

The more popular titles were Office Sirulation, Model office, Office Practice, and office Procedures. They were mentioned by 49 per cent of the office simulation teachers as being the course title used in their respective schools.

Question 3--If simulation is a part of another class, please give the name (s) of the class(es).

In the schools where office simulation is incorporated into other business classes, office practice, advanced typing, and office procedures 
were the courses most frequently used for the simulation. Thesc three classes were 1 isted by 59 per cent of the teachers responding to this question.

There were 26 different course titles cited by the 56 tenchers responding to this question. Some schools had more than one class of which simulation was a part. The course titles and the number of teachers reporting each are listed below.

\section{Course Titles}

Officc Practice

Advanced Typing or Typing II

Office Procedures

Secretarial Cluster

Busincss Lab

Business Machincs

Senior Business Lab

Business Procedures

Open Lab

Secretarial office Practice

Vocational office Occupations

Career Officc Education

Coop Office Education

Office Techniques

Office Occupations

Secretarial Procedures

Advanced Shorthand

Office Work Experiencc

Senior Business Lab

Block

Office Lab

Office Practice and Procedures

Accounting office Skills

Office Machines

Clerical Cluster

Business English

No Response
No. Responding

16

10

7

3

3

2

2

1

1

1

1

1

1

1

1

1

1

1

1

1

1

1

1

1

1

1

3

Question 4-- For how long is the simulation class taught?

For the office simulation class, almost half ( 49 per cent) of the teachers reported that the class is taught for a full year. 
Table 1 and futurc tables divide the responses into two catcgories. The first category shows the responses of all simulation teachers responding to the questionnaire. The second category is for responses from teachers who offer a course in office simulation which is not a part of another class.

TABLE 1

LENGTI OF TIME USED FOR SIMUIATION

(RESPONSES TO QUESTION 4)

\begin{tabular}{|c|c|c|c|c|}
\hline \multirow{2}{*}{ Item } & \multicolumn{2}{|c|}{ A11 Responses } & \multicolumn{2}{|c|}{ Simulation Class } \\
\hline & $\begin{array}{l}\text { No. of } \\
\text { Responses }\end{array}$ & Pcrcent & $\begin{array}{l}\text { No. of } \\
\text { Responses }\end{array}$ & Pcrcent \\
\hline Full-ycar class & 28 & 28 & 22 & 49 \\
\hline One-semester class & 22 & 22 & 15 & 33 \\
\hline Nine-weck class & 22 & 22 & 6 & 16 \\
\hline A unit in another class & 17 & 17 & & \\
\hline Integrated with other classes & 12 & 12 & & \\
\hline
\end{tabular}

Other time periods mentioned werc sjx weeks, seven weeks, two trimesters, twelve wocks three times a year, and fifteen wecks. Onc tcacher mentioned that simulation was done through indjvidual lcarning packages of a different number of week's duration. Another teacher has the students use five cassettes, which contain simulation exercises. Iach cassctte takes about two wecks to complete. Another teacher has the students on a three-day-per-weck rotation schedule. One teacher did not answer the question. 
Question 5--What are the prerequisites of the simulation class?

The majority of the teachers of office simulation requirc typing as a prerequisite to office simulation or to the class in which office simulation is offered. Ninety-three schools require typing, which is ninetythree per cent of the schools reporting office simulation in their business curriculum. Eight teachers reported that they do not require typing for their office simulation.

There are a number of schools that do not have a grade standing requirement for the office simulation. Twenty-four teachers did not mark a grade standing as a prerequisite. Almost half (45 per cent) of the 101 simulation teachers allow students to take classes offering simulation as juniors. Thirty-six per cent of the independent simulation class tcachers offer the class to juniors.

Only one teacher has a GPA requirement, which is at least a "C."

Table 2 shows the responses to Question 5.

TABLI: 2

PREREQUISITES OF TIIE CLASSES IN MIICH SIMULATION IS TAUGIT (RESPONSES TO QUUESTION 5)

\begin{tabular}{|c|c|c|c|c|}
\hline \multirow[b]{2}{*}{ Item } & \multicolumn{2}{|c|}{ A11 Responses } & \multicolumn{2}{|c|}{ Simulation Class } \\
\hline & $\begin{array}{c}\text { No. of } \\
\text { Responses }\end{array}$ & Percent & $\begin{array}{c}\text { No, of } \\
\text { Responses }\end{array}$ & Percent \\
\hline Typing I & 68 & 67 & 31 & 69 \\
\hline Typing II & 25 & 25 & 10 & 22 \\
\hline Business Machines & 24 & 21 & 7 & 12 \\
\hline Bookkecping/Accounting & 8 & 8 & 3 & 5 \\
\hline Shorthand I & 9 & $?$ & 4 & 9 \\
\hline Business Math & 4 & 4 & 0 & 0 \\
\hline General Business & 3 & 3 & 2 & 4. \\
\hline Junior standin! & 45 & 45 & 21 & 36 \\
\hline Senior standing & 2.3 & 23 & 10 & 17 \\
\hline Sophomore standing & $?$ & 9 & 3 & 5 \\
\hline Teacher approval & 29 & 29 & i1 & 19 \\
\hline None & 3 & 3 & 2 & 4 \\
\hline GPA & 1 & 1 & 1 & 2 \\
\hline
\end{tabular}


There were a number of other prerequisites mentioned by the teachers. They were:

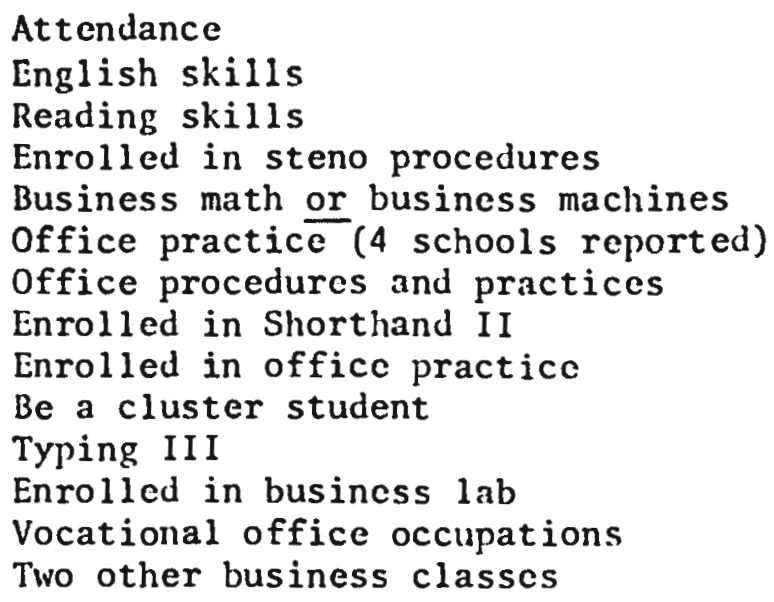

Question 6--For what block of time docs the simulation class meet?

The most popular way of teaching simulation is in the 50 -minute block (the time length of the period as reported by the teachers ranged from 40 to 55 minutes with the majority using 50 minutes) five days a weck. of the 101 schools, 64 tcach their simulation classes for approximately 50 minutes per day five days a weck.

Table 3 shows very little difference hetween the percentages for all simulation taught and simulation taught as a class separate from other classes.

Some schools reported that they offered their classes for threc hours per weck; five forty-minute periods per week; onc, two, threc hours per day (varies according to the preference of the students); and six hours per week (two hours per day on Monday, Wednesday, and Friday).

Question 7-- What text or materials are uscd for simulation?

More schools used the Lester llill Corporation matcrials than any of the other materials. Sccond most frequently mentioned was personal ma- 
terials. Six schools have their students do actual work for tenchers and the community. Table 4 shows the various materials used by the teachers in their office simulations.

TABLE 3

RESPONSES TO TIE BLOCK OF TIME THE CLASSES OF SINULATION MEET (RESPONSES TO QUESTION (i)

\begin{tabular}{|c|c|c|c|c|}
\hline \multirow{2}{*}{ Item } & \multicolumn{2}{|c|}{ All Responses } & \multicolumn{2}{c|}{ Simulation class } \\
\cline { 2 - 5 } & $\begin{array}{c}\text { No. of } \\
\text { Responses }\end{array}$ & Percent & $\begin{array}{c}\text { No. of } \\
\text { Responses }\end{array}$ & Percent \\
\hline 5 hours (50 min.) per week & 64 & 63 & 28 & 62 \\
15 hours per week & 35 & 35 & 16 & 36 \\
\hline
\end{tabular}

TABLF, 4

TEXTS OR MUTERIALS USER FOR SIMMLATION (RESPONSES TO QUESTION 7)

\begin{tabular}{|c|c|c|c|c|}
\hline \multirow{2}{*}{ Item } & \multicolumn{2}{|c|}{ All Responses } & \multicolumn{2}{|c|}{ Simulation Class } \\
\hline & $\begin{array}{l}\text { No. of } \\
\text { Responses }\end{array}$ & Percent & $\begin{array}{l}\text { No. of } \\
\text { Responses }\end{array}$ & Percent \\
\hline $\begin{array}{l}\text { Lester llill Corporation } \\
\text { Personal Materials } \\
\text { Gregg Office Job Training } \\
\text { Indio Paper Co., Inc. } \\
\text { Executive Offices of Am. } \\
\text { Serendipity, Inc. } \\
\text { APEX } \\
\text { No answer }\end{array}$ & $\begin{array}{r}47 \\
26 \\
16 \\
15 \\
14 \\
9 \\
4 \\
3\end{array}$ & $\begin{array}{r}47 \\
26 \\
16 \\
15 \\
14 \\
9 \\
4 \\
3\end{array}$ & $\begin{array}{r}16 \\
15 \\
6 \\
3 \\
4 \\
3 \\
3 \\
1\end{array}$ & $\begin{array}{r}36 \\
33 \\
13 \\
5 \\
9 \\
5 \\
5 \\
2\end{array}$ \\
\hline
\end{tabular}


Other materials mentioned were:

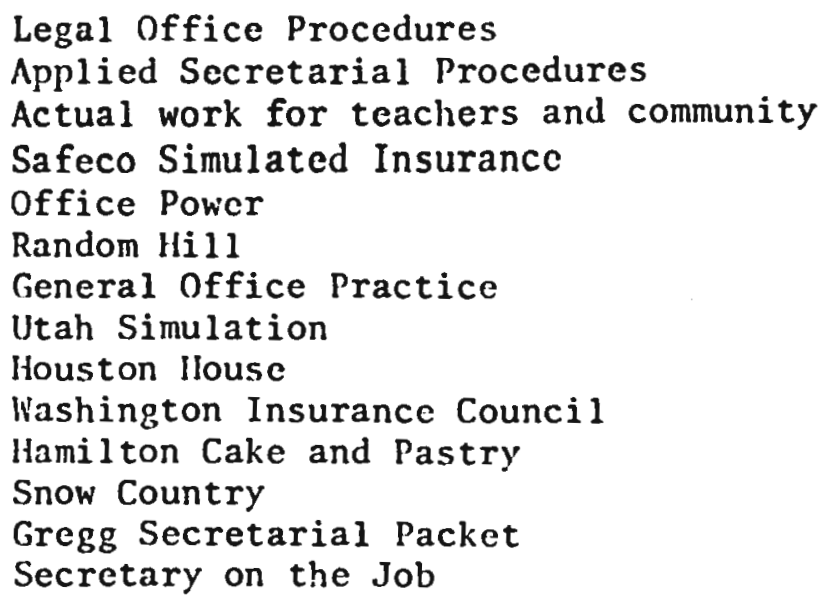

Question 8-- What equipment is used in the simulation?

Electric typewriters and electronic calculators proved to be the most used equipment among the Oregon teachers. Over 90 per cent of the teachers reported the use of them. The ten-key adding machine was also a popular item used by 84 per cent of the teachers.

There are not many posting machines or key punch machines in use. Only two schools reported that they used them.

It is interesting to note that 13 schools use the full-keyhoard listing machine although this is not a popular piece of business equipment in business offices today.

Seven teachers reported that they use real telephone equipment rather than practice equipment. Some use the central switchboard for the school having the students spend a certain amount of time on it. Some indicated that they have real telephones in the classroom.

Table 5 illustrates the various equipment used in the schools offering office simulation. 
TABLE: 5

BUSINESS EQUIPMENT IN USE IN OREGON SCIDOLS

(RESPONSES TO QUESTION 8)

\begin{tabular}{|c|c|c|c|c|}
\hline \multirow{2}{*}{ Equipment } & \multicolumn{2}{|c|}{ A1l Responses } & \multicolumn{2}{|c|}{ Simulation Class } \\
\hline & $\begin{array}{l}\text { No. of } \\
\text { Responses }\end{array}$ & Percent & $\begin{array}{l}\text { No. of } \\
\text { Responses }\end{array}$ & Percent \\
\hline $\begin{array}{l}\text { Spirit duplicator } \\
\text { Mimeograph } \\
\text { Mimeoscope } \\
\text { offset machine } \\
\text { Photocopier } \\
\text { Thermofax } \\
\text { Electric typewriters } \\
\text { Manual typewriters } \\
\text { Long carriage typewriter } \\
\text { Executive typewriters } \\
\text { Memory typewriter } \\
\text { Projector } \\
\text { Overhead } \\
\text { Collator } \\
\text { Posting machine } \\
\text { Practice telcphone cquip. } \\
\text { Key punch machinc } \\
\text { Postage meter } \\
\text { Filing cabinets } \\
\text { Key-driven calculator } \\
\text { Electronic calculator } \\
\text { Ten-key adding machine } \\
\text { Full-keyboard listing mach. } \\
\text { Transcribers }\end{array}$ & $\begin{array}{r}74 \\
59 \\
30 \\
8 \\
44 \\
41 \\
98 \\
37 \\
37 \\
20 \\
10 \\
10 \\
26 \\
17 \\
2 \\
57 \\
2 \\
5 \\
80 \\
18 \\
92 \\
84 \\
13 \\
52\end{array}$ & $\begin{array}{r}73 \\
58 \\
30 \\
8 \\
14 \\
41 \\
97 \\
37 \\
37 \\
20 \\
10 \\
10 \\
26 \\
17 \\
2 \\
56 \\
2 \\
5 \\
79 \\
15 \\
91 \\
83 \\
13 \\
51\end{array}$ & $\begin{array}{r}28 \\
23 \\
11 \\
4 \\
21 \\
16 \\
37 \\
15 \\
14 \\
7 \\
5 \\
1 \\
13 \\
7 \\
1 \\
23 \\
0 \\
2 \\
31 \\
5 \\
34 \\
29 \\
5 \\
23\end{array}$ & $\begin{array}{r}62 \\
51 \\
24 \\
9 \\
47 \\
36 \\
82 \\
33 \\
31 \\
16 \\
11 \\
9 \\
29 \\
16 \\
2 \\
51 \\
0 \\
4 \\
69 \\
11 \\
76 \\
64 \\
11 \\
51\end{array}$ \\
\hline
\end{tabular}

In addition to the equipment listed in Table 5, other pieces of equipment were reported as being used. They were:

\author{
Cassettes \\ Paper cutter \\ Electric stapler \\ Cash register \\ Time clock \\ Switchboard \\ Self-correcting II typewiter \\ Check protector \\ On-line terminal
}


Question 9--Rank the criteria used for evaluating students according to the value placed on that item.

This question seemed to be a more difficult one to answer. Eighteen teachers made no attempt to rank the evaluation criteria. The reasons given by several teachers were that the items were too difficult to rank and that they were of equal importance. Sixteen teachers ranked the criteria as one or two rather than from one to ten.

To obtain a ranking for those ranked one and two, an average was taken for the ones and an average for the twos. For example, if five items were marked one and five items were marked two, the ones were added together as $1+2+3+4+5=15$ and then divided by five $(15 \div 5)$ for a rank of three. Each of the five items was then marked as a three. The same way of ranking was used for the items marked two; i.e., $6+7+8+$ $9+10=40 \div 5$ or 8 . Each of the items ranked as two was given a rank of eight on the table. The same method of averaging was used for any items that were marked of equal rank.

Table 6 illustrates the ranking of the evaluation criteria for all schools where office simulation is taught. Table 7 shows the data for the office simulation classes which are not incorporated in other husiness classes.

There was not a great difference shown hetween the two groups. They were similar in rank except for mailability and cffort and improvement. iajlability, for example, was ranked second by all teachers. llowever, it was ranked sixth by the teachers of the office simulation class. Effort and improvement and cooperation were also ranked higher by the office simulation class teachers than by all the teachers responding to the question. 
As illustrated in Table 6, mailability was ranked sccond as a factor considered in evaluating students; yet 17 teachers did not rank it as a factor to consider in evaluating students. This may be explained by the fact that some teachers felt that mailability was inherent in quality of work. Ten teachers made this comment. The 17 teachers who did not rank the mailability item may have had the same thought in mind. Other tcachers marked quality of work as one; and mailability as nine or ten.

In the literature reviewed for this study, one of the purposes of simulation was found to be to bring together the skills learned previously and develop the attitudes necessary for on-the-job performance. This may explain why attainment of skill and knowledge was ranked in the lower half of the 1 ist and attitudes, effort, and cooperation were in the top half.

Some evaluation criteria which were not listed on the questionnaire but were mentioned by teachers as being important were:

interpersonal relations supervisory and decision making leadership ability

One teacher also mentioned that the employees grade each other.

Question $10--1$ low often are iob positions rotated?

The length of time on each job varics from those where stulents do not change job positions to those who change once a weck. The most popular length of time mentioned at one position was four weeks. Table 8 shows the teachers' responses to this question.

Twenty-two per cent of the simulation class teachers did not rotate the students from joh to job. The materials used by these tenchers were: 
TABLE 6

RANK OF CRITERIA IISED TO EVALUATE SIMULATION STUDENTS

BY TIIE VALUE TEACHERS PIACED ON EACII ITEM

(ALL CLASSES IN WIICII SIMULATION IS TAUGIT)

(RF:SPONSES TO QUESTION 9)

\begin{tabular}{|c|c|c|c|c|c|c|c|c|c|c|c|c|}
\hline \multirow[b]{2}{*}{ Criteria } & \multicolumn{12}{|c|}{ No. of Teachers Ranking Evaluation Criteria } \\
\hline & 1 & 2 & 3 & 4 & 5 & 6 & 7 & 8 & 9 & 10 & $\begin{array}{l}\text { not } \\
\text { ranked }\end{array}$ & $\begin{array}{l}\text { mean } \\
\text { rank }\end{array}$ \\
\hline Quality of work & 30 & 28 & 5 & 4 & 7 & 0 & 5 & 0 & 4 & 0 & 1 & 2.69 \\
\hline Slailability & 6 & 21 & 7 & 5 & 6 & 3 & 4 & 3 & 8 & 2 & 17 & 4.32 \\
\hline Attitude toward work & 6 & 6 & 12 & 10 & 19 & 12 & 5 & 3 & 2 & 1 & 7 & 4.58 \\
\hline Effort and improvement & 6 & 4 & 13 & 5 & 15 & 13 & 4 & 6 & 3 & 1 & 12 & 4.84 \\
\hline Coopcration & 3 & 9 & 6 & 13 & 9 & 13 & 10 & 6 & 5 & 1 & 8 & 5.16 \\
\hline Attendance & 7 & 4 & 11 & 10 & 13 & 8 & 6 & 6 & 6 & 7 & 5 & 5.32 \\
\hline Attainment of skill \& knowledge & 2 & 3 & 9 & 9 & 16 & 7 & 4 & 8 & 9 & 4 & 12 & 5.72 \\
\hline Initiative & 1 & 4 & 3 & 11 & 15 & 12 & 6 & 10 & 4 & 5 & 12 & 5.87 \\
\hline quantity & 3 & 7 & 6 & 7 & 3 & 10 & 6 & 6 & 7 & 18 & 9 & 6.45 \\
\hline Mecting deadlines & 0 & 0 & 8 & 7 & 7 & 8 & 8 & 6 & 7 & 10 & 22 & 6.59 \\
\hline
\end{tabular}


TABLE 7

RANK OF CRITLRIA USED TO EVALUATE SI:UULATION STUDENTS

BY THE VALUE TTACIIEPSS PLACED ON EACI ITEM

(SIMULATION CLASS)

(RESPONSES TD QUESTION 9)

\begin{tabular}{|c|c|c|c|c|c|c|c|c|c|c|c|c|}
\hline \multirow{2}{*}{ Criteria } & \multicolumn{12}{|c|}{ No. of Teachers Ranking Evaluation Criteria } \\
\hline & 1 & 2 & 3 & 4 & 5 & 6 & 7 & 8 & 9 & 10 & $\begin{array}{l}\text { not } \\
\text { ranked }\end{array}$ & $\begin{array}{l}\text { mean } \\
\text { rank }\end{array}$ \\
\hline Quality of work & 13 & 11 & 2 & 1 & 7 & 0 & 2 & 0 & 2 & 0 & 0 & 2.95 \\
\hline Effort and improvement & 4 & 3 & 4 & 3 & 7 & 4 & 0 & 2 & 0 & 0 & 9 & 4.04 \\
\hline Cooperation & 1 & 6 & 1 & 9 & 5 & 5 & 1 & 1 & 1 & 0 & 7 & 4.37 \\
\hline Attitude toward work & 4 & 1 & 6 & 4 & 8 & 3 & 2 & 2 & 1 & 0 & 6 & 4.42 \\
\hline Attendance & 4 & 2 & 7 & 3 & 5 & 4 & 4 & 0 & 3 & 2 & 3 & 4.85 \\
\hline Hailability & 2 & 5 & 3 & 3 & 4 & 1 & 2 & 2 & 2 & 2 & 11 & 4.88 \\
\hline Attainment of skill $;$ knowledge & 1 & 1 & 8 & 1 & 7 & 2 & 3 & 2 & 3 & 1 & 8 & 5.24 \\
\hline Initiative & 0 & 2 & 0 & 6 & 9 & 4 & 1 & 3 & 1 & 3 & 8 & 5.76 \\
\hline Quantity of work & 2 & 5 & 2 & 4 & 1 & 2 & 0 & 2 & 5 & 7 & 6 & 6.07 \\
\hline 'lecting deadlines & 0 & 0 & 0 & 2 & 6 & 3 & 5 & 2 & 2 & 4 & 13 & 6.88 \\
\hline
\end{tabular}

Eight teachers did not answer the question.

Eight teachers did not rank the criteria correctly. 
Materials Used

Personal Materials

Lester Hill Corporation

Indio Paper Co., Inc. (Practice Set)

Gregg office Job Training

Executive Offices of America (Practice Set)

Legal office Procedures
No. of Teachers

4
2
2
2
2
1

The types of materials used may have something to do with not rotating the students. However, the Lester llill Corporation and Gregg Office Job Training materials are designed so that students may be rotated among the job positions.

TABLE 8

LENGTII OF TIME SPENT ON JOB POSITIONS

(RESPONSES TO QUESTION 10)

\begin{tabular}{|l|r|r|r|r|}
\hline \multirow{2}{*}{ Length of Time } & \multicolumn{2}{|c|}{ All Responses } & \multicolumn{2}{|c|}{ Simulation Class } \\
\cline { 2 - 5 } & $\begin{array}{c}\text { No. of } \\
\text { Responses }\end{array}$ & Percent & $\begin{array}{c}\text { No. of } \\
\text { Responses }\end{array}$ & Percent \\
\hline One week & 8 & & 5 & 11 \\
Two weeks & 10 & 10 & 3 & 7 \\
Three wecks & 10 & 10 & 3 & 7 \\
Four weeks & 17 & 17 & 11 & 24 \\
Five weeks & 1 & 1 & 1 & 2 \\
Six wecks & 3 & 3 & 3 & 7 \\
Nine weeks & 6 & 6 & 2 & 4 \\
Not rotated & 23 & 23 & 10 & 22 \\
Varies with unit & 14 & 14 & 4 & 9 \\
Two times a year & 2 & 2 & 1 & 2 \\
Student request & 1 & 1 & 0 & 0 \\
No answer & 7 & 7 & 2 & 4 \\
\hline
\end{tabular}

Question 11--llow are students selected for job positions?

Sixty-two per cent of the teachers responding stated that students make application for their job positions. Fifty per cent were selected for the specific job according to their ability. The questionnaire did not ask how the students were tested for ability. Thirty-six per cent were sclected through interviews. 
The responses of the teachers to this question were as follows:

\section{Criteria}

Student application

Ability of student

Interviews

Weaknesses of student

Teacher judgment

Recommendations

No answer

Rotate through all jobs

Entrance cxam

Pretesting

Interest and skills inventory
No. of Responses

62

50

36

10

7

4

4

2

1

1

Question 12--How many credits per year are given simulation students?

In order to get a more complete picture, the responses to Question 12 were combined with the responses from Questions 4 and 6.

For the Simulation Class, two credits for ten hours per weck for the full year and one credit for five hours per weck for the full ycar were the more popular assiguments of credit. Table 9 shows the different methods of assigning credits to students of the simulation classes.

A weakness in the questionnaire appears here. Different teachers responded to this question in different ways. Some teachers answered the question pertaining to the entirc class of which simulation is a part. Others answered the question for only the simulation unit of the class. The responses received from all the simulation teachers are listal in Table 10.

Different schools assign different hours of credit for the sabe length of time. For example, one school might award one hour of crelit for onehour class for the full year. Another may give one-hour credit for a onehour class per semester or per nine weeks. This sizould be taken into consideration in evaluating the information provided hy the virious schools. 
TABLE 9

CREDITS ASSIGNED TO SIMULATION CLASS

(RESPONSES TO QUESTION 12)

\begin{tabular}{|c|c|c|c|}
\hline Credits & Hours Per leek & Length of class & $\begin{array}{c}\text { No. of } \\
\text { Responses }\end{array}$ \\
\hline 2 & 10 & full year & 9 \\
1 & 5 & full year & 7 \\
$1 / 2$ & 5 & one semester & 6 \\
1 & 5 & one semester & 4 \\
2 & 5 & full year & 3 \\
$1 / 4$ & 5 & nine weeks & 2 \\
4 & 10 & full year & 2 \\
2 & 10 & onc semester & 1 \\
$1 / 4$ & 10 & nine weeks & 1 \\
2 & 10 & ninc weeks & 1 \\
1 & 10 & nine weeks & 1 \\
$1 / 2$ & 5 & nine wecks & 1 \\
1 & 10 & one scriester & 1 \\
5 & 5 & one semester & 1 \\
2 & 5 & nine weeks & 1 \\
1 & 5 & no answer & 1 \\
1 & 5 & two trincsters & 1 \\
3.3 & 5 & oncek term & 1 \\
1 per period & 5, or 15 & onc semester & 1 \\
\hline
\end{tabular}

Question 13--1 low many students are cnrolled in your school?

More large schools offer separate simulation classes. Table 11 shows that more schools with a student body over 1000 have separate simulation classes. A higher percentage of medium-sized schools offer simulation as a part of other business classes taught.

Only two schools with a student body under 100 have simulation classes. This may be explained by the fact that these schools are not close to businesses and the community does not lend itself to this type of class. Also in small schools, the curriculum offerings are more limited than in the larger schools.

Eight schools indicated that they will be having office simulation heginning the fall of 1977 . These schools were not included in Table 11. 
TABLE 10

CREDITS ASSIGNED TO CLASSES IN WHIICI SIMULATION IS TAUGIT (RESPONSES TO QUESTION 12)

\begin{tabular}{|c|c|c|c|}
\hline Credits & $\begin{array}{l}\text { Hours } \\
\text { Per Week }\end{array}$ & Length of Class & $\begin{array}{l}\text { No. of } \\
\text { Responses }\end{array}$ \\
\hline $\begin{array}{c}2 \\
1 \\
1 / 2 \\
1 / 4 \\
1 \\
1 \\
2 \\
1 \\
2 \\
1 \\
\text { unusable answer } \\
2 \\
4 \\
2 \\
\text { no answer } \\
1 / 4 \\
2 \\
1 / 2 \\
1 / 4 \\
1 \\
1 / 2 \\
1 \\
5 \\
1 \\
2 \\
\text { no answer } \\
1 / 4 \\
2 \\
1 \\
\text { per period } \\
\text { no answer } \\
2 \\
1 \\
2 \\
1 / 2 \\
\text { no answer } \\
2 \\
1 / 2 \\
3.3 \\
\text { anser } \\
\text { no }\end{array}$ & 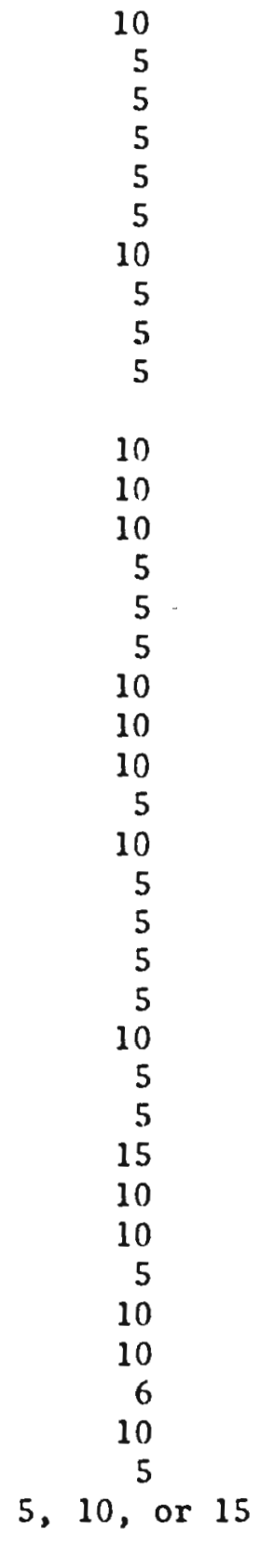 & $\begin{array}{l}\text { full year } \\
\text { full year } \\
\text { one semester } \\
\text { nine weeks } \\
\text { one semester } \\
\text { unit in another class } \\
\text { nine weeks } \\
\text { nine weeks } \\
\text { full year } \\
\text { no answer } \\
\text { one semester } \\
\text { full year } \\
\text { unit in another class } \\
\text { unit in another class } \\
\text { unit in another class } \\
\text { integrated } \\
\text { nine weeks } \\
\text { nine wecks } \\
\text { nine weeks } \\
\text { nine wecks } \\
\text { one semester } \\
\text { onc scmestcr } \\
\text { two trimesters } \\
\text { nine wecks } \\
\text { l5 weeks } \\
\text { three week unit } \\
\text { six weeks } \\
\text { integrated } \\
\text { integrated } \\
\text { integrated } \\
\text { unit in another class } \\
\text { unit in another class } \\
\text { unit in another class } \\
6 \text { to } 12 \text { wecks } \\
\text { unit in another class } \\
\text { one semester } \\
12 \text { week term } \\
\text { one semester } \\
\text { ning }\end{array}$ & $\begin{array}{r}12 \\
12 \\
8 \\
6 \\
5 \\
5 \\
4 \\
4 \\
3 \\
3 \\
3 \\
2 \\
2 \\
2 \\
2 \\
2 \\
2 \\
2 \\
1 \\
1 \\
1 \\
1 \\
1 \\
1 \\
1 \\
1 \\
1 \\
1 \\
1 \\
1 \\
1 \\
1 \\
1 \\
1 \\
1 \\
1 \\
1 \\
1 \\
1 \\
1\end{array}$ \\
\hline
\end{tabular}


TABLE 11

SIZE OF OREGON SCHOOLS IN RELATIONSHIP TO

WHETHER OR NOT SIMULATION IS TAUGHT

AND WHETIIER IT IS A CLASS OR COORDINATED IN OTHER CLASSES

(RESPONSES TO QUESTION 13)

\begin{tabular}{|c|c|c|c|c|c|c|}
\hline \multirow{2}{*}{$\begin{array}{c}\text { Size of } \\
\text { School }\end{array}$} & \multicolumn{2}{|c|}{$\begin{array}{c}\text { Affirmative } \\
\text { Responses }\end{array}$} & \multicolumn{2}{c|}{$\begin{array}{c}\text { Negative } \\
\text { Responses }\end{array}$} & \multicolumn{2}{c|}{$\begin{array}{c}\text { Simulation } \\
\text { Class }\end{array}$} \\
\cline { 2 - 7 } & $\begin{array}{c}\text { No. of } \\
\text { Responses }\end{array}$ & $\begin{array}{c}\text { Percent by } \\
\text { Classif. }\end{array}$ & $\begin{array}{c}\text { No. of } \\
\text { Responses }\end{array}$ & $\begin{array}{c}\text { Percent by } \\
\text { Classif. }\end{array}$ & $\begin{array}{c}\text { No. of } \\
\text { Responses }\end{array}$ & Percent \\
\hline Smal1 & & & & & & \\
$0-99$ & 7 & 54 & 6 & 46 & 2 & 4 \\
$100-299$ & 16 & 57 & 12 & 43 & 7 & 16 \\
Medium & & & & & & \\
$300-499$ & 16 & 76 & 5 & 24 & 7 & 16 \\
$500-999$ & 29 & 74 & 10 & 26 & 13 & 29 \\
Large & & & & & & \\
over 1000 & 31 & 70 & 13 & 30 & 16 & 36 \\
\hline
\end{tabular}

Question 14--How many students are cnrolled in office simulation?

The responses to Question 13 were combined with the responses of Question 14 to present a clearer picture of the relationship between the class size and the size of the school. Table 12 shows this relationship.

The more popular class size is from 11 to 20 students followed by the class size of 0 to 10 students.

Question 15--llow many classes of simulation are offercd?

The responses to Questions 13 and 14 were used along with Question 15 to obtain the information for Table 13. This shows how many simulation classes are taught and the size of the classes in relation to the size of the school.

Table 14 shows the same type of information as Table 13 except that it shows the responses from all business teachers of simulation. 
TABLE 12

CLASS SIZE IN RELATIONSIIIP TO SIZE OF SCIOOL.

(RESPONSES TO QUESTIONS 13 AND 14)

\begin{tabular}{|c|c|c|c|c|c|c|c|c|c|c|}
\hline \multirow{3}{*}{$\begin{array}{l}\text { No. of } \\
\text { Students } \\
\text { in Class }\end{array}$} & \multicolumn{10}{|c|}{ Size of Student Body } \\
\hline & \multicolumn{5}{|c|}{ Al1 Responses } & \multicolumn{5}{|c|}{ Simulation Class } \\
\hline & $\begin{array}{l}0- \\
99\end{array}$ & $\begin{array}{l}100- \\
299\end{array}$ & $\begin{array}{l}300- \\
499\end{array}$ & $\begin{array}{l}500- \\
999\end{array}$ & $\begin{array}{l}\text { over } \\
1000\end{array}$ & ח? & $\begin{array}{l}100- \\
299\end{array}$ & $\begin{array}{l}300- \\
49 !\end{array}$ & $\begin{array}{l}500- \\
090\end{array}$ & $\begin{array}{l}\text { over } \\
1000\end{array}$ \\
\hline $0-10$ & 6 & 9 & 5 & 5 & 4 & 2 & 3 & 4 & 2 & 1 \\
\hline $11-20$ & 1 & 5 & 9 & 14 & 14 & 0 & 3 & 1 & 9 & 9 \\
\hline $21-30$ & 0 & 1 & 1 & 10 & $S$ & 0 & 0 & 0 & 4 & 7 \\
\hline over 30 & 0 & 0 & 2 & 1 & 6 & 0 & 0 & 0 & 1 & 3 \\
\hline
\end{tabular}

Simulation is taught in different classes and different clusters. This would account for several sections of small classes. In Table 14, for example, two schools have two classes of less than ten students in each. Several teachers indicated on the questionnajre that simulation was taught in more than one class in their schools.

Question 16--What learning takes place that students cannot get in other classes taught in your school, such as office practice and work experience?

Teachers tend to agree that work-flow experience, dependjug on work of others and coordinating skills with on-the-joh demands are three things learned in simulation that are not learned in other classes. Tahle 15 shows how the teachers responded to this question.

Some other responses from teachers are as follows:

Organization of self and work

Getting along with others 
TABLE 13

NUMBER OF INDEPENDENT SIMULATION CLASSES TAUGIT

AND NUMBER OF STUDENTS ENROLLED IN CLASSES

IN RELATIONSHIP TO TIE SIZE OF TIE SCIOOL

(RESPONSES TO QUESTIONS 13, 14, and 15)

\begin{tabular}{|c|c|c|c|}
\hline $\begin{array}{l}\text { Size of } \\
\text { Student } \\
\text { Body }\end{array}$ & $\begin{array}{l}\text { No. of } \\
\text { Students } \\
\text { in Class }\end{array}$ & $\begin{array}{l}\text { No. of } \\
\text { Classes }\end{array}$ & $\begin{array}{l}\text { No. of } \\
\text { Responses }\end{array}$ \\
\hline $\begin{array}{r}0-99 \\
100-299\end{array}$ & $\begin{array}{l}0-10 \\
0-10\end{array}$ & $\begin{array}{l}1 \\
1\end{array}$ & $\begin{array}{l}2 \\
2\end{array}$ \\
\hline $100-299$ & $0-10$ & 2 & 1 \\
\hline $100-299$ & $11-20$ & 1 & 3 \\
\hline $100-299$ & $21-30$ & 1 & 1 \\
\hline $300-499$ & $0-10$ & 1 & 3 \\
\hline $300-499$ & $11-20$ & 1 & 3 \\
\hline $300-499$ & $11-20$ & 2 & 1 \\
\hline $500-999$ & $0-10$ & 1 & 1 \\
\hline $500-999$ & $11-20$ & 1 & 7 \\
\hline $500-999$ & $11-20$ & 3 (9 wh. classes) & 1 \\
\hline $500-999$ & $21-30$ & 1 & 1 \\
\hline $500-999$ & $21-30$ & 2 & 2 \\
\hline $500-999$ & over 30 & 2 & 1 \\
\hline over 1000 & $0-10$ & 1 & 1 \\
\hline over 1000 & $11-20$ & 1 & 5 \\
\hline over 1000 & $11-20$ & 2 & 2 \\
\hline over 1000 & $21-30$ & 1 & 4 \\
\hline over 1000 & $21-30$ & 2 & 1 \\
\hline over 1000 & over 30 & 2 & 1 \\
\hline over 1000 & over 30 & 3 & 1 \\
\hline over 1000 & over 30 & 7 & 1 \\
\hline
\end{tabular}


TABLE 14

RESPONSES OF ALL SIMULATION TEACHERS AS TO THE NUMBER OF CLASSES TAUGIT AND NUMBER OF STUDENTS ENROLLED IN CLASSES

IN RELATIONSIIIP TO TIIE SIZE OF TIE SCIOOL

(RESPONSES TO QUESTIONS 13, 14, AND 15)

\begin{tabular}{|c|c|c|c|}
\hline $\begin{array}{l}\text { No. in } \\
\text { Student } \\
\text { Body }\end{array}$ & $\begin{array}{l}\text { No. of } \\
\text { Students } \\
\text { in Class }\end{array}$ & $\begin{array}{l}\text { No. of } \\
\text { Classes }\end{array}$ & $\begin{array}{l}\text { No. of } \\
\text { Responses }\end{array}$ \\
\hline $\begin{array}{l}0-99 \\
0-99 \\
0-99 \\
100-299 \\
100-299 \\
100-299 \\
100-299 \\
100-299 \\
300-499 \\
300-499 \\
300-499 \\
300-499 \\
300-499 \\
300-499 \\
500-999 \\
500-999 \\
500-999 \\
500-999 \\
500-999 \\
500-999 \\
\text { over } 1000 \\
\text { over } 1000 \\
\text { over } 1000 \\
\text { over } 1000 \\
\text { over } 1000 \\
\text { over } 1000 \\
\text { over } 1000 \\
\text { over } 1000 \\
\text { not answered }\end{array}$ & $\begin{array}{l}0-10 \\
0-10 \\
11-20 \\
0-10 \\
0-10 \\
11-20 \\
11-20 \\
21-30 \\
0-10 \\
11-20 \\
11-20 \\
21-30 \\
\text { over } 30 \\
\text { over } 30 \\
0-10 \\
11-20 \\
11-20 \\
21-30 \\
21-30 \\
\text { over } 30 \\
0-10 \\
11-20 \\
11-20 \\
21-30 \\
21-30 \\
\text { over } 30 \\
\text { over } 30 \\
\text { over } 30\end{array}$ & $\begin{array}{l}1 \\
2 \\
1 \\
1 \\
2 \\
1 \\
2 \\
1 \\
1 \\
1 \\
2 \\
2 \\
2 \\
3 \\
1 \\
1 \\
3 \\
1 \\
2 \\
2 \\
1 \\
1 \\
2 \\
1 \\
2 \\
2 \\
3 \\
1\end{array}$ & $\begin{array}{r}5 \\
1 \\
1 \\
8 \\
1 \\
4 \\
1 \\
1 \\
5 \\
5 \\
3 \\
1 \\
1 \\
1 \\
4 \\
13 \\
1 \\
5 \\
5 \\
1 \\
4 \\
11 \\
3 \\
6 \\
2 \\
2 \\
2 \\
1 \\
3\end{array}$ \\
\hline
\end{tabular}


Decision making

At tendance

Leadership

Two teachers did not answer the question

No one does the job for the students

TABLE 15

LEARNING THAT TAKES PLACE IN SIMULATION THAT IS NOT OBTAINED ELSEWHERE (RESPONSES TO QUESTION 10)

\begin{tabular}{|c|c|c|c|c|}
\hline \multirow{2}{*}{ Item } & \multicolumn{2}{|c|}{ Al1 Responses } & \multicolumn{2}{|c|}{ Simulation Class } \\
\hline & $\begin{array}{l}\text { No. of } \\
\text { Responses }\end{array}$ & Percent & $\begin{array}{l}\text { No. of } \\
\text { Responses }\end{array}$ & Percent \\
\hline Work-flow experience & 80 & 79 & 37 & 82 \\
\hline $\begin{array}{l}\text { Coordinate skills with } \\
\text { demands on the job }\end{array}$ & 68 & 67 & 34 & 76 \\
\hline Depending on work of others & 68 & 67 & 33 & 73 \\
\hline Maturity development & 45 & 45 & 22 & 49 \\
\hline Letter composition & 30 & 30 & 18 & 40 \\
\hline $\begin{array}{c}\text { Closely supervised work } \\
\text { experience }\end{array}$ & 29 & 29 & 16 & 36 \\
\hline
\end{tabular}

Question 17--Ihy was the program implemented in your school?

A self-desire was expressed by 66 per cent of the teachers as the reason why the simulation program was implemented in their school. Table 16 shows the other responses of the simulation teachers.

The teachers responding to the questionnaire gave other reasons for implementing a simulation program in their school. The reasons given are as follows:

Entry level training

Opportunity for non achievers 
Relevancy to the world of work (suggested by two teachers)

District decision to attract good students

Motivational device

Believed best for the students

New way to teach bookkeeping

Need in the school itself

Teacher asked for it for ten years

To lure boys to business education

To fulfill career education hours requirement

Best use of equipment and instructors

Declining enrollment in business

School service

Student need

TABLE 16

RESPONSES TO QUESTION 17:

WII WAS THE PROGRAM IMPLEMENTED IN YOUR SCIOOL?

\begin{tabular}{|c|c|c|c|c|}
\hline \multirow{2}{*}{ Item } & \multicolumn{2}{|c|}{ All Responses } & \multicolumn{2}{|c|}{ Simulation Class } \\
\hline & $\begin{array}{l}\text { No. of } \\
\text { Responses }\end{array}$ & Percent & $\begin{array}{l}\text { No. of } \\
\text { Responses }\end{array}$ & Percent \\
\hline Self-desire & 67 & 66 & 28 & 62 \\
\hline $\begin{array}{l}\text { Recommendation of fellow } \\
\text { cducators }\end{array}$ & 25 & 25 & 10 & 22 \\
\hline Demands of business & 17 & 17 & 9 & 20 \\
\hline Available funds & 16 & 16 & 12 & 27 \\
\hline Demands of students & 11 & 11 & 7 & 16 \\
\hline $\begin{array}{l}\text { Recommended by advisory } \\
\text { committee }\end{array}$ & 9 & 9 & 7 & 16 \\
\hline Already in school & 5 & 5 & 4 & 9 \\
\hline No answer & 3 & 3 & 1 & 2 \\
\hline
\end{tabular}

Question 18--Ihat problems were encountered in setting up the simulation progran?

The three main problems experienced by simulation teachers were scheduling difficulties ( 46 per cent), teacher preparation time ( 43 per 
cent), and lack of equipment ( 37 per cent). Sixteen per cent of the teachers stated that they had no problems in sctting up the program. The responses of the teachers are shown in Table 17.

TABLE: 17

PROBLEMS ENCOUNTERED IN SETTINF UP TIIE SIMULATION PROGRAM (RESPONSES TO QUESTION 18)

\begin{tabular}{|c|c|c|c|c|}
\hline \multirow{2}{*}{ Problems } & \multicolumn{2}{|c|}{ All Responses } & \multicolumn{2}{|c|}{ Simulation Class } \\
\hline & $\begin{array}{c}\text { No. of } \\
\text { Responses }\end{array}$ & Percent & $\begin{array}{c}\text { No. of } \\
\text { Responses }\end{array}$ & Percent \\
\hline Schcduling difficulties & 46 & 46 & 24 & 53 \\
\hline Teacher preparation time & 43 & 43 & 15 & 33 \\
\hline Lack of equipment & 37 & 37 & 17 & 38 \\
\hline Lack of funds & 24 & 24 & 13 & 29 \\
\hline None & 16 & 16 & 5 & 11 \\
\hline Lack of student interest & 11 & 11 & 4 & 9 \\
\hline No answer & 5 & 5 & 2 & 4 \\
\hline Lack of facilities & 4 & 4 & 4 & 9 \\
\hline
\end{tabular}

Other problems named by simulation teachers were:

Sctting up busincss Insecurity of teacher Class time too short

Question 19--What promotional methods are used to encourage students to take the simulation class?

Over half of the teachers surveyed indicated that they depended on student recommendations (59 per cent) and counselor recommendations (53 per cent) for promoting the class to students. Forty-scven per cent 
used presentations in other classes to encourage enrollment in the simulation program. The percentages were slightly higher in the simulation class with 62 per cent using student recommendations, 56 per cent using counselor recommendations, and 53 per cent using presentations in other classes.

The teacher responses to Qucstion 19 are illustrated in Table 18.

TABLE 18

PRONOTIONAL METHODS USED

TO ENCOURAGE STUDENTS TO TAKE TIIE SIMULATION CLASS

(RESPONSES TO QUESTION 19)

\begin{tabular}{|c|c|c|c|c|}
\hline \multirow{2}{*}{ Method } & \multicolumn{2}{|c|}{ A11 Responses } & \multicolumn{2}{|c|}{ Simulation Class } \\
\hline & $\begin{array}{c}\text { No. of } \\
\text { Responses }\end{array}$ & Percent & $\begin{array}{c}\text { No. of } \\
\text { Responses }\end{array}$ & Percent \\
\hline Student recommendation & 59 & 58 & 28 & 62 \\
\hline Counselor recommendation & 53 & 52 & 25 & 56 \\
\hline Presentations in classcs & 47 & 47 & 24 & 53 \\
\hline Brochures & 19 & 19 & 10 & 22 \\
\hline Teacher counseling & 7 & 7 & 4 & 9 \\
\hline Slides & 7 & 7 & 3 & 7 \\
\hline None & 5 & 5 & 3 & 7 \\
\hline No answer & 5 & 5 & 2 & 4 \\
\hline Department recruitment & 3 & 3 & 2 & 4 \\
\hline Career unit credit & 2 & 2 & 2 & 4 \\
\hline
\end{tabular}


Several other promotional methods were cited as being used by simulation teachers. They are:

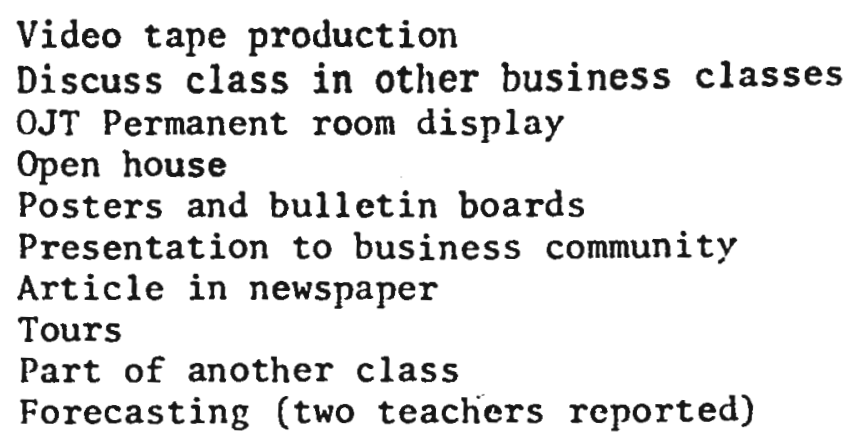

Question 20--Rank the following objectives as to their importance to your simulation program.

This question was borrowed from the questionnaire of Condor and Rainey (12:18-21) in their study of office practice education. The list of ohjectives werc expanded for this study.

The list of objectives rated by the Orcgon teachers are the oljectives mentioned most frequently by professional writers. The ratings were made in the order of the importance the teachers placed on them in their simulation program.

Seventy-two of the one hundred and one simulation teachers answered this question correctly. Nincteen teachers chose not to answer the question and ten ranked several of the objectives as equal. In order to use the responses of the ten teachers who ranked the objectives as equal, an average was taken and assigned to the objective.

In order to determine how the teachers ranked the objectives, the mean score of each objective was figured. The objective with the lowest mean was determined as objective Number 1 .

The objective ranked first was to help students develop desirable work habits such as ability to organizc, to follow directions, and to bc 
thorough and efficient. Twenty-one teachers ranked this as the most important objective. Twenty-four additional teachers ranked this as second in importance. Fifteen teachers did not mark this objective, so they evidently didn't feel it was important to their program.

Twenty-one teachers also ranked the objective, to develop acceptable character, personality traits, and work habits important to the business office, as number one. Ninetcen selected it as second in importance. The mean rank placed this objective as second in importance. It is interesting to note that this objective was rated as number one in the Condor and Rainey study. The number one objective in this study was not included in the Condor, Rainey study. Sixteen teachers did not feel that this objective was important enough to rank.

The objective ranked third in importance was to understand the organization and flow of work of the busincss office. Fourteen teachers placed this objective first. An additional nine teachers marked it as second in importance.

Tables 19 and 20 show the ratings of the simulation teachers and the simulation class teachers. The simulation class teachers ranked the same three objectives as the top three as did all the simulation teachers. Eighteen teachers left out this objective in ranking the objectives important to their program.

The objectives, as listed in the questionnaire, are as follows:

1. To develop acceptable character, personality traits, and work habits important to the business office.

2. To improve and coordinate office skills learned in other courses.

3. To understand the organization and flow of work of the business office. 
4. To build a background knowledge of business principles, office organization, and occupational information.

5. To develop an acquaintanceship skill in the use of machines commonly found in an office.

6. To further develop skills in the typing of various business forms and in proofreading.

7. To develop skill in filing and in records management.

8. To develop work simplification techniques in the office.

9. To develop skill in looking for and in applying for an office position.

10. To provide an informational background of performed duties which a beginner in an office may be called upon to perform.

11. To help develop occupational maturity by enriching their background of business information.

12. To acquaint students with business standards and requirements.

13. To help students develop desirable work habits such as ability to organize, to follow directions, and to be thorough and efficient.

14. To provide opportunity for students to develop the ability to evaluate their work and the work of others.

In addition to the objectives listed on Tables 19 and 20 , the following objectives were added by some of the teachers:

To give experience in and understanding of the importance of interpersonal relations in an office.

Familiarity with business papers, purchase orders, invoices, etc.

To serve the school and teachers in completing office projects.

To understand confidentiality in conduct.

To help motivate students towards business careers. 
TABLE 19

OBJECTIVES RANKED AS TO IMPORTANCE TO ALL CLASSES OFFERING SIMULATION (RESPONSES TO RUESTION 20)

\begin{tabular}{|c|c|c|c|c|c|c|c|c|c|c|c|c|c|c|c|c|c|}
\hline \multirow[b]{2}{*}{$\begin{array}{c}\text { Objective } \\
\text { Number }\end{array}$} & \multicolumn{17}{|c|}{ Number of Teachers Responding to Objectives } \\
\hline & 1 & 2 & 3 & 4 & 5 & 6 & 7 & $\varepsilon$ & $S$ & 1 & 11 & 1 & 2 & 13 & 14 & $\begin{array}{c}\text { No } \\
\text { Answer }\end{array}$ & $\begin{array}{l}\text { Mean } \\
\text { Rank } \\
\end{array}$ \\
\hline 13 & 21 & 24 & 11 & 9 & 5 & 5 & 3 & 1 & & & 0 & & 1 & 0 & 0 & 15 & 3.01 \\
\hline 1 & 21 & 19 & 8 & 11 & 6 & 5 & 4 & 3 & & & 0 & & 1 & 1 & 0 & 16 & 3.41 \\
\hline 3 & 14 & 9 & 13 & 8 & 2 & 8 & 6 & 4 & & & 2 & & 2 & 3 & 1 & 18 & 4.95 \\
\hline 2 & 6 & 9 & 12 & 8 & 11 & 8 & 6 & 7 & & & 1 & & 3 & 1 & 0 & 18 & 5.26 \\
\hline 10 & 5 & 3 & 4 & 9 & 4 & 8 & 9 & 18 & & & 3 & & 4 & 0 & 3 & 24 & 6.81 \\
\hline 12 & 1 & 4 & 8 & 3 & 11 & 10 & 7 & 7 & & & 4 & & 4 & 2 & 2 & 25 & 6.89 \\
\hline 4 & 0 & 3 & 5 & 5 & 8 & 12 & 7 & 2 & & & 7 & & 6 & 1 & 0 & 27 & 7.31 \\
\hline 14 & 2 & 2 & 4 & 7 & 10 & 10 & 5 & & & & 7 & & 2 & 3 & 6 & 25 & 7.42 \\
\hline 11 & 1 & 1 & 5 & 5 & 11 & 6 & 11 & 3 & & & 7 & & 2 & 5 & 0 & 26 & 7.44 \\
\hline 6 & 0 & 0 & 6 & 6 & 3 & 8 & 4 & $\varepsilon$ & & & 8 & & 9 & 2 & 0 & 25 & 7.89 \\
\hline 9 & 0 & 0 & 1 & 5 & 7 & 8 & 2 & & & & 2 & & 4 & 7 & 4 & 35 & 8.57 \\
\hline 5 & 1 & 2 & 1 & 3 & 1 & 3 & 2 & 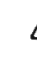 & & 1 & 14 & & 3 & 8 & 4 & 33 & 9.59 \\
\hline 7 & 0 & 2 & 0 & 2 & 2 & 5 & 6 & & & & $\xi$ & & 9 & 9 & 4 & 34 & 9.66 \\
\hline 8 & 0 & 0 & 0 & 2 & 2 & 5 & 5 & 5 & & & & & 6 & 11 & 14 & 34 & 10.45 \\
\hline
\end{tabular}


TABLE 20

OBJECTIVES RANKED AS TO IMPORTANCE TO THE INDEPENDENT SIMULATION CLASS (RESPOINSES TO QUESTION 20)

\begin{tabular}{|c|c|c|c|c|c|c|c|c|c|c|c|c|c|c|c|c|}
\hline \hline $\begin{array}{c}\text { Objective } \\
\text { Number }\end{array}$ & 1 & 2 & 3 & 4 & 5 & 6 & 7 & 8 & 9 & 10 & 11 & 12 & 13 & 14 & $\begin{array}{c}\text { No } \\
\text { Nnswer }\end{array}$ & $\begin{array}{c}\text { Mean } \\
\text { Rank }\end{array}$ \\
\hline 13 & 10 & 11 & 4 & 4 & 2 & 3 & 2 & 0 & 0 & 0 & 0 & 1 & 0 & 0 & 1 & 3.08 \\
1 & 9 & 8 & 3 & 7 & 2 & 3 & 3 & 1 & 0 & 0 & 0 & 1 & 0 & 0 & 1 & 3.54 \\
3 & 3 & 4 & 7 & 5 & 1 & 3 & 5 & 0 & 0 & 2 & 1 & 1 & 2 & 0 & 4 & 5.26 \\
2 & 2 & 2 & 3 & 6 & 3 & 4 & 4 & 4 & 2 & 1 & 1 & 2 & 1 & 0 & 3 & 6.11 \\
4 & 0 & 2 & 4 & 3 & 5 & 6 & 4 & 1 & 5 & 1 & 2 & 0 & 0 & 0 & 5 & 6.12 \\
10 & 3 & 3 & 2 & 2 & 2 & 5 & 4 & 2 & 1 & 3 & 3 & 0 & 0 & 1 & 7 & 6.23 \\
12 & 1 & 1 & 3 & 1 & 6 & 6 & 5 & 2 & 0 & 3 & 3 & 0 & 0 & 1 & 7 & 6.56 \\
11 & 0 & 1 & 4 & 0 & 6 & 4 & 6 & 0 & 2 & 3 & 5 & 0 & 2 & 0 & 5 & 7.24 \\
9 & 0 & 0 & 1 & 3 & 3 & 6 & 2 & 2 & 4 & 0 & 2 & 1 & 4 & 1 & 9 & 8.00 \\
6 & 0 & 0 & 2 & 3 & 2 & 3 & 4 & 4 & 1 & 6 & 3 & 3 & 1 & 0 & 6 & 8.03 \\
14 & 2 & 0 & 1 & 2 & 4 & 4 & 2 & 3 & 1 & 2 & 4 & 1 & 2 & 4 & 5 & 8.19 \\
5 & 0 & 1 & 0 & 2 & 1 & 2 & 2 & 1 & 2 & 6 & 6 & 1 & 2 & 1 & 11 & 9.07 \\
7 & 0 & 0 & 0 & 2 & 0 & 2 & 6 & 2 & 1 & 2 & 5 & 4 & 3 & 1 & 10 & 9.39 \\
8 & 0 & 0 & 0 & 1 & 1 & 3 & 3 & 1 & 1 & 1 & 1 & 5 & 4 & 5 & 12 & 10.31 \\
\hline
\end{tabular}


Question 21--Is the Simulation class meeting the objectives desired?

Sixty-nine out of one hundred and one teachers felt that the simulation program is mecting the objectives they desire. Only four teachers reported that they did not feel the objectives were being met. Fourteen teachers felt that they did not know whether or not the objectives were being met, and cleven did not answer the question. Table 21 shows how the teachers answered the question.

TABLE 21

RESPONSES TO QUESTION 21:

IS TIIE SIMULATION CLASS MEETING THE OBJECTIVES IDESIRED?

\begin{tabular}{|l|c|c|c|c|}
\hline \multirow{2}{*}{ Item } & \multicolumn{2}{|c|}{ All Responses } & \multicolumn{2}{c|}{ Simulation Class } \\
\cline { 2 - 5 } & $\begin{array}{c}\text { No. of } \\
\text { Responses }\end{array}$ & Percent & $\begin{array}{c}\text { No. of } \\
\text { Responses }\end{array}$ & percent \\
\hline Yes & 69 & 68 & 33 & 73 \\
No & 4 & 4 & 1 & 2 \\
No answer & 14 & 14 & 5 & 11 \\
Partially & 11 & 11 & 3 & 1 \\
\hline
\end{tabular}

Question 22--Any additional comments would be greatly appreciated.

Following are the unedited comments from various teachers:

"First week or so should be spent on practice runs with order processing--entire class should first sce one order followed all the way through."

"We are constantly called by cmploycrs asking for students from our program." 
"The 'real' work concept is one in which we firmly believe... and it is a major contributor to the success of the program. During the fourth quarter of the cluster class, the students go out and work in the community (spending three weeks in three different jobs). The students come away from these jobs with employer recommendations... and this is a strong promotion for the class."

"My model office work consists of jobs given to the girls by the teachers. Model office runs Monday-Wednesday-Friday, with Tuesday and Thursday reserved for typing drills and timings. Although I plan to have a much better program next year, I have found that by having the girls work for 'real people' rather than simulated jobs, they become very conscience of their work and skills."

"please feel free to call me as to the reasons we abandoned the simulation. The materials, etc. were adequate and all developed by one other teacher and myself."

"Serendipity is out of place in Advanced Typing. We have been using it eight weeks, and the students are getting restless. The 0JT Series is fantastic."

"Student motivation and interest is tremendous always."

"This project required many hours of preparation; but now we are operating, I see the results and they are vory sutisfying."

"We did well with this program when we had a two-hour block of time provided. Since then we have been--for the most part--on a flexible schedule on which the students report to regular classes three days a week for 50-minute periods and 'flex' (go where they want) two days a week. At the present, we are back on a regular schedule or 50-minute class poriods five days a week." 
"Wc changed from fixed classes of advanced shorthand and onc-half year business law and one-half year of business machines to the open business lab. We really gained a great deal, because with the individualized learning packages, we can teach everything from payroll accounting to memory typewriter to you name it--vocabulary, duplication, cash register, Gestetner reproduction. North Bend set up the model for the state on this-we have some setup.. . It really works! Lot of work to set up learning packets."

One teacher offered the following information in a letter explaining her program:

I use the OJT units as short units to teach mail handling; accounts payable; accounts receivable; filing (in some cases); cashiering; and other short units in recordkeeping. Typing II, and sometimes in office practice.

Indio Paper Company is used as a final project in Typing II; Executive Offices of America is used as a special project in beginning office practice and the Lester llill, Inc. simulation is used as a final project in office practice.

Lester Hill is the only one actually treated as a simulation and is taught the second semester of office practice. I have had several students go through the Lester llill simulation two years in a row because there were jobs in the simulation they had not had a chance to try and they wanted to do so.

In the Lester llill simulation, I place my grcatest cmphasis for grading upon attendance. All absences must be made up or the student's grade is lowered. Their grades are given in the form of a pay check every week. I have worked out a bonus and deduction system, and each student must do some extra work to receive a bonus in order to receive an "A" grade for that wcek. Bonus pay is given for such things as preparing an office bullet in board or calendar; helping another employce with his job, etc. Deductions in pay are made for tardiness; not clcaning up their work area; unsatisfactory performance on the job, etc. The students seem to like the grading system, and it has worked very well for me.

"It is an excellent device to point out to students how cooperation plays an important part in an office. Student attendance is definitely 
stressed. If they are absent, it creates a problem within their unit-other students have to take on part of their work load, etc. Students checking other students' work . . they learn to be more careful about what they do; and perhaps.. . not to criticize quite so loudly. It has been a fun experience. This is the first year for a one-period class; it has been two in the past, but I changed classes from Shorthand II to clerical office practice. One period is definitely not long enough."

"We tried one class of simulation by itself and had trouble with number enrolled. Seems to be working well in with office practice class. Marketing class runs the student store and this is going very well."

"I believe the Lester Hill simulation is an extremely motivating learning tool. My students enjoy having their own desk to decorate and like to be able to improve their grade by working overtime. I had thought students might not think the work was 'real', but they do-they take their jobs very seriously. I am a real advocate of office simulations."

"For several years I used Lester Hill. I didn't think it was secretarial enough for my students. Also the repetition of the same forms and type of work performed (even though rotated in departments) was not the most satisfactory learning experience in my eyes."

"Development of leadership and cooperation evident. Ability to work under pressure tested. Self reliance--responsibility for own work measured."

"We tried this for one year. It had some real positive aspects. Perhaps it may have been my lack of preparation time that made me decide to return to the traditional classroom. I had several other things--I started off with a unit on secretarial workers, etc. We then had a four- 
week unit on the dictaphones--both transcribing and dictating on cassette, sheet and disc. This was followed by a four-week unit on filing before ever getting into the simulation. I felt they did not get the mailing, postal, itinerary, and other units. I felt that it would have been good for accounting rather than for secretarial office practice."

"I have used Lester Hill's simulation for four years. Each year we buy new materials and forms. My students really enjoy it. Attendance improves and they do learn work flow and the importance of accurate work."

"The simulation class is a part of my office specialities class."

"Have a two-hour business procedure class ( 3 students) so answers refer to that class."

"We aren't meeting the objectives because our class is more like a business lab rather than office simulation. We are in the process of making it more like a simulation. We don't have a business machines class. For next year, I am planning to do the machine projects first semester and set up a better simulation for the second semester."

"Extremely rewarding to teach. Even though I use the simulation as part of another class, it is neat to see girls develop in lcadershipmanagement skills. It is easy to become very attached to them. Time is the big hangup--there is never enough."

"Still needs some revisions as concerns procedures, etc."

"As each year passes the program becomes more important as a culminating activity for our students."

"Most students view the simulation as just another class--for which they carn just another grade. The simulated pay checks do not make much difference in motivation. Furthermore, a simulation is very difficult 
to grade. Ordinarily, in a real office, either the worker does well enough to be kept on the job or is fired for incompetence. Not so in the simulated classroom--a raise in simulated pay does very little to increase pride. Our sophomore simulation accomplishes what it purports to, but it is not nearly so ambitious a project as APEX. Start simple!"

"It is hard for a 'traditional' business teacher to 'allow' students the freedom this class offers as it is highly unstructured and not all students produce all of the time."

"Our situation is a little different than many schools. Our lab is completely individualized, and the students pick their course of study according to what business occupation they choose. Our room is set up to simulate an office, and job attitudes are very much a part of the program and evaluation. We are not, however, running a company such as Lester Hill. Students are working in many different areas."

"It's my favorite class to teach. There is enough time to really help the students and not just skim the surface."

"Could have two classes if there were funds available. Also have senior office lab (not described here) which is a production class for the school (tickets, programs, mailings, teacher handouts, etc.) composed mainly of CWE students ( 30 of them!)"

"I tried the Lester Hill for two years--the students who knew some bookkeeping liked it, but too many in the class had no experience in bookkeeping and could not keep up, and then the absentee problem, too, created havoc--as it would in a real office. We just did not seem to like it, so now we use the office job training series of Gregg, and they pick two of 
these, plus typewriting kits, as Snow Country, and the South-Western Filing packet."

"Model office needs to be two hours to accomplish its goal of 'realism' ."

"Program is written up in Small School Practices--for a further overview."

"We are a new program, two years old; so we are still developing and changing the class."

"The course is extremely hard to grade but is tremendously rewarding to both the students and the teacher. I would never, never go back to teaching any other way."

"Students in my simulation are really finding out how important regular attendance is when others are depending on them."

"I would like to try a simulation which is more secretary-oriented. Lester Hill is good, but is very accounting-oriented."

"I think next year we will have another simulation in office procedures."

"Coop work experience is a valuable part of the program."

"Great program! for beginners or advanced students."

"I have been using this simulation for five years. All materials are available free from Safeco Insurance Company. In the past, I have only accepted seniors. Since seniors cannot attend school part time to pick up their requireds, I am having difficulty attracting enough students. Next year I will open it up to 11 th graders."

"We are in process of revising. Main problems have been getting release time for planning and available materials." 
"I am going to provide more opportunities for feedback from the teacher to the students." 


\section{CHIAPTER V}

\section{PLAN OF IMPLEMENTATION}

\section{Introduction}

The office simulation program in the Reynolds High School will be implemented in the fall of 1978 in the new Columbia High School. The program also includes the students from Reynolds High School.

The materials selected to be used for this program are SAFECO, printed by the Washington Insurance Council and Lester llill Corporation materials published by the Gregg Division of the McGraw-Hill Book Company. By using these two simulations, two different types of businesses are presented offering the students a broader experience.

SAFECO and Lester llil1 Corporation are more accounting oriented than secretarial. Therefore, a stenographic pool will be added as a separate department of these two businesses. Materials for the stenographic pool will be prepared by the teacher. The stenographic employees will also do production work for the school.

Each office simulation student will spend one full day in an actual business office working and observing the operations of that organization.

\section{Objectives of office Simulation}

The following objectives will be used in teaching the office simulation class:

1. To help students develop desirable work habits such as ability to organize, to follow directions, and to be thorough and efficient. 
2. To develop acceptable character, personality traits, and work habits important to the business office.

3. To understand the organization and flow of work of the business office.

4. To improve and coordinate office skills learned in other classes.

5. To provide an informational background of performed duties which a beginner in an office may be called upon to perform.

6. To acquaint students with business standards and requirements.

7. To build a background knowledge of business principles, office organization, and occupational information.

8. To provide opportunity for students to develop the ability to evaluate their work and the work of others.

9. To help develop occupational maturity by enriching the students' background of business information.

10. To further devclop skills in the typing of various business forms and in proofreading.

11. To develop skill in looking for and in applying for an office position.

Assessment of Student and Community Needs

The Portland area will be surveyed in order to determine the types of businesses in which graduates will be employed. The training needs for beginning workers, the types of equipment which the beginning workers will be using, and the business skills needed will be worked into the simulation. The questionnaire, illustrated in the appendix on page 111 will be sent to appropriate businesses during the year prior to the year in which the simulation is taught. A card (illustrated on page 113 of the appendix) 
will be prepared for each business showing specific information pertinent to that business. The card is then used to place students for a day in a business office or for help in placing students in jobs after graduation. The office simulation class enrollment is dependent upon the information available to the counselors and students. They must be aware of the activities of the program before an interest in taking the class can be developed by the student.

A memorandum will be sent to each guidance counselor explaining the office simulation program. The counselors, through interest and aptitude tests, can recommend the program to the students interested in office occupations. The counselors can also help in publicity, placement, and program evaluation activities.

A survey will be conducted in all business classes to identify the students interested in the office simulation program. The questionnaire used is illustrated on page 114 of the appendix.

\section{Publicity}

In order for the office simulation program to be a success, the businesses, the community, parents, teachers, and students must be aware of the program and of what it consists.

The following methods will be used to inform the public of the simulation program:

1. Business teachers will explain the program to students in other business classes.

2. The simulation teacher will visit the other business classes at preregistration time to explain the program.

3. Office simulation students will talk to other students about the program. 
4. A sumnary of the class activities will be provided for the counselors and administrators.

5. Articles will be submitted to the local newspaper. Reporters will be invited to the classroom to take pictures of the class in action.

6. Slides and movies will be taken of the class in action and will be shown at City Council meetings, Chamber of Commerce meetings, service organizations, school board meetings, faculty meetings, freshman orientation meetings, etc.

7. An advisory committee will be formed to provide a source for getting information to the public through personal conversations with associates. The advisory committee is further explained on page 93.

8. Graduates of the program who have been successful in office occupations will be asked to speak to various groups and to appear in the films. Success stories of the graduates will be printed in the school newspaper and in the bulletins, which will be sent to all district residents.

9. Field trips and outside speakers will provide an opportunity for involvement with businesses. They will then become aware of the existence of the program.

10. Open house will be held during the latter part of the third nine weeks. Business people, parents, school board members, administrators, counselors, teachers, and interested students will be invited to attend.

11. Brochures will be prepared by the graphic art students and will be distributed with preregistration materials.

Equipment

Most of the equipment and supplies needed for the office simulation program are already available in the classroom where the simulation will 
be taught. Following is a list of the equipment and supplies suggested

by the writer:

Equipment

secretarial desks

posture chairs

electric typewriters

calculators

long-carriage typewriter

executive typewriter

dictating and transcribing machines

collator

four-drawer filing cabinets

telephones and switchboard

mimeoscope

paper cutter

photocopier mimeograph machine

postage scale

staple remover

postage meter

scissors and rulers

time clock

desk organizer

tape recorder and players

memory typewriter

paper punch

magazine rack

$35 \mathrm{~mm}$ slide camera

Supplies

office Job Training materials

Lester llill Corporation materials

lettersize file folders

employees withholding certificates

current social security and weekly income tax withholding tables

W-2 forms

carbon paper

typing bond paper

second sheets

\# 10 envelopes

staplers and staples

paper clips

trays for $81 / 2 \times 11$-inch paper

stencils

masters

dictating machine tapes

blank cassettes

duplicating paper

mimeograph paper

typing ribbons

typing erasers

adding machine tape

duplicating fluid/ink

scotch tape

ZIP Code directory

time cards

time sheets

payroll summary sheets

telephone message pads 
hand cleaner

mimeograph styli

mimeograph lettering guides

telephone directory

dictionaries

postal information and regulations

secretarial handbooks

professional magazines

transportation schedules

\section{Selection of Students}

Students from both Reynolds High School and Columbia High School will apply for entrance into the office simulation program by filling out an application form (illustrated on page 115 of the appendix) prior to registration for the next school year. The simulation teacher will schedule an interview with the interested students. The form that will be filled out during the interview is illustrated on page 117.

The main things the teacher will look for during the interview with the students applying for the program are:

1. A sincere desire to be employed as an office worker upon graduation or to continue full-time study in the field of business.

2. Existing business skills and qualifications for office work.

3. Attendance during the past year.

4. Students willing to spend two periods per day for a full school year in the simulation class.

5. Students willing to conform to business standards of dress and attitudes.

6. Willingness to work and dependability.

Implementation

Office simulation should be taken as closely to the student's entry into the business world as possible. Therefore, junior students who are 
three-year graduates or have indicated a desire to complete a two-year simulation program will be admitted into the office simulation program. Other students will wait until their senior year to take the class.

In the scheduling of the office simulation class, every effort will be made to schedule it so that it does not conflict with the required classes for seniors and other business classes taught to seniors.

The students will attend the office simulation class two hours per day and receive two credit hours for completing the course satisfactorily. Hopefully, all students who apply for the office simulation program will be admitted. However, the number accepted will be determined by the number of worker stations available.

Twenty-eight work stations will be provided as shown in the room layout chart on page 120. Thus a maximum of 28 students will he admitted to the class. A minimum of ten students must enroll in the simulation class before it can be offered.

Pretests will be administered during the first week of school. The results of these tests will be used to determine the strengths and weaknesses of the simulation students and to place the students in the various job positions.

Review of Materials to be Used

SAFECO will be used the first scmester of the simulated office class. It is an insurance simulation printed by the Washington Insurance Council. It has three basic components--"Simulated Insurance Manual", a specific procedure and rate manual for student use; "Simulated Insurance Forms", a teacher's manual and forms; and "The You in Simulation", a teacher's manual to help plan the simulation program. 
The Washington Insurance Council also offers many other free materials such as filmstrips, flow charts, wall charts, auto insurance applications, good student discount applications, endorsements, etc.

An insurance company provides an ideal simulation since there are an abundance of insurance companies which provide job opportunities to entrylevel workers. Agents are located in small towns as well as large cities. SAFECO is designed for a two-hour block of time for a full year but. can be easily adjusted for one-semester. It requires one year of typewriting and is suggested for senior students. However, it will be offered to junior students who are interested in taking two years of office simulation. During the second year of the class, the students may go through any positions they missed during the first year if they so desire. Mainly, they will hold administrative positions and do promotional work.

Students desiring shorthand as part of the simulation can easily be included in the SAFECO simulation. It is also a good program to attract boys, as many men are employed by the insurance industry.

Twenty-one different pretests are included to be given the first week of the simulation. These tests cover typing, machine transcription, filing, business arithmetic, spelling, grammar, punctuation, letter composition, and information services. The scores of each student will be determined and ranked from high to low. It is then suggested that during the second week the students should be paired according to highest and lowest, second highest and second lowest, etc. Each pair forms an agency to be continued throughout the semester.

The next five weeks is typically used for presimulation activities. The package is designed for rotation of students during this time. The students will be introduced to procedures, documents, equipment, and vocabu- 
lary, grooming, telephone manners, application procedures, references, resumes and interviewing techniques. Group presentations will be given at this time on such things as a rating lesson by someone from the insurance company, the proper use of the telephone by a telephone company representative or a film, and a grooming and office manners presentation by personnel from the Trend Business Schools or by a representative of the National Secretaries Association.

The best student should enter the simulated office first to take care of the opening activities. As the first student opens the model office (the parent company), the agents will open the training laboratory. During the presimulation activities, the agencies will apply for and receive a bank loan of $\$ 1,000$. The parent company will make an opening deposit of $\$ 50,000$. At the end of the month, the parent company and all the agencies will pay the monthly expenses such as heat, lights, telephone, bank loan, postage, and janitorial services. Premiums from the insurance policies sold and commissions from the company will provide the income.

It is suggested that the driver education students be used as customers. Fact sheets will be sent to the driver education teacher who will have the driver education students fill out and return the forms. These forms will be equally distributed among the agencies. The agents will write letters for appointments and interviews with the driver education students. They will interview these customers, determine the governing driver, symbol of cars insured, and factors applied to base premiums. The completed forms will then be sent to the company where they will be evaluated and underwritten. A completed policy will then be given by the agent 
to the driver education student. Agents may seek out other customers such as friends, teachers, and parents. The agencies that bring in the most business will receive the greatest income.

Students who have been in the parent company and are rotated to an agency will be allowed at least one week with their agent-partners to catch up on what is happening. An agent and partner will never be in the parent company at the same time.

"Training trips" are a part of the SAFECO program. Students showing weaknesses in a certain area (determined by the pretest and observations of the teacher) will be sent on a "training trip." The student will go on the "training trip" in another city. The student will plan his own itinerary and make reservations for travel and hotel acconmodations. The student will stay physically in the classroom but goes through a period of training as if he were away. When finished with the training, the student will apply for reimbursement of expenses which will be deposited in the agency bank. One student will be designated as a banker and will take care of posting the checks and deposits to the bank ledgers and preparing monthly statements.

Several options may be added to the simulated materials in SAFECO. $\Lambda t$ the end of the semester, each agency may prepare an income and expense statement. In January, a special tax accountant may be appointed to prepare $\mathbb{W}-2$ forms and to prepare the necessary tax forms for the parent company. Each agency may also prepare income tax reports.

Accident claims may be incorporated into the program. One or two students may act as customers and call agents to report automobile accidents. A good student may act as the claims adjuster. The auto shop students of the school may be used to prepare the estimates of the losses. 
One of the important factors of this simulation is the involvement of other people outside the simulation class. Besides other students involved, the actual insurance company within the community will be involved by providing resource people, forms and documents, actual procedures, and flowcharts. Representatives from the insurance company will also be used to teach certain parts of the program to the students. (62)

The Lester Hill Corporation is a simulated national distributor of equipment and supplies to hotels, motels, and other residential institu= tions. It will have branch offices of which the teacher acts as the executive vice president in charge of office operations. The students function as employees in the branch offices.

Each branch office will have the following four departments: (1) Sales, (2) Warehouse, (3) Traffic, and (4) Accounting. Each department will have a general manager. The customers, suppliers, and bank will be called Tallidata.

The Lester llill simulation package consists of:

(1) An Employee's Manual, which explains the company's organization and contains organization charts, system flowcharts, job descriptions, company policies, duties of department managers, routines and procedures for each department, departinental orientation exercises, information sheets for customers and suppliers, job application form, transfer request forms, suggestion forms, weekly work reports, and a company catalog.

(2) An Employer's manual, which explains how to conduct the simulation. It suggests ways of setting up the classroom, introducing the simulation to the students, supervising the daily operations, and adding optional activities. It also contains a key for the orientation exercises. 
(3) The supply room contains all the materials and supplies needed. A shelved box is included to store the blank forms.

There are three different office systems operating within the Lester Ilill Corporation.

(1) Sales system. The sales department will prepare the shipping order from the customer's order form. Warchouse will update the inventory; traffic will prepare the freight memorandum; and accounting will prepare the invoices, make the necessary ledger entries, and send the invoice to the customer. When a check is received for the goods, it will be routed to the accounting department where it will be recorded and deposited in the bank. When stock runs low, warehouse will notify the purchasing department.

(2) Purchasing department. The purchasing department will prepare the purchase order and send it to the supplier. The supplier, Tallidata, will prepare the invoice and return it. Warehouse will update the inventory and send the invoice to accounting. Accounting will make the necessary entries and prepare the check and send it to the supplier.

(3) Cash control. The bank will keep track of all the deposits and withdrawals. A bank statement will be prepared and sent with the cancelled checks to the accounting department. The accounting department will then reconcile the bank statement.

The employee will be evaluated each week by his supervisor and the teacher. Forms for the evaluation are included in the package.

Each student will be paid a base salary of $\$ 65$ per week. Bonuses or deductions will be made according to the student's attendance, punctuality, quality and quantity of work, attitude, conduct, reaction to suggestions and criticisms, etc. The maximum salary that can be earned is $\$ 100$, which represents a grade of 100 . 
About 15 hours will be used for presimulation activities. During this time the students will apply for specific jobs and will be interviewed. After the employees are hired for their specific jobs, they will meet with their managers, set up their departments, and completc several orientation exercises.

When the first order comes in the operations will begin. A system of checks and balances has been worked into the routines and procedures. The employees will audit all papers that cross their desks. It is up to them to detect and correct all errors. The teacher will make daily and weekly checkups to be sure the work is being done correctly.

An employee will be temporarily reassigned to help catch up on work that is backlogged or to fill in for an absent employee. Reassignment of workers will be done at any point. New jobs will be assigned as soon as any position has been mastered. Hopefully, all students will have a chance to rotate through all six positions. (63)

\section{Rotation of Students}

Students will be assigned to their original job positions according to their specified interests and abilities. They will remain in this position until the job has been learned and the student is functioning well within that position. Changes will be considered upon the request of the student, the supervisor, or the teacher. Not all students will be rotated at the same time. Hopefully, all stuclents will be rotated through all jobs. llowever, this is not a must. Some students may have no desire or interest in working in some positions. They may also not have the basic skills needed such as accounting for the accounting department or typing and shorthand for the secretarial pool. All students, however, will rotate through all the machines until a working knowledge of each is acquired. 
Evaluation

Does the office simulation class really prepare the students for the challenges they will receive in actual work? In order to answer this question, two evaluations must take place--a course evaluation and a student evaluation.

Course Evaluation. In order to determine whether or not the course objectives are being met, information may be obtained from the following sources:

(1) A survey of graduates to detcrmine whether or not the course helped the worker on the job.

(2) Employers should be surveyed to see how effective the former simulation student is on the job.

(3) Guidance counselors and other teachers may have information on whether or not the student has improved in work habits, attitudes, and dependability.

A survey of the graduate and employer may also provide information on whether or not the right things are being taught. A sample of the surveys can be found on pages 121 and 128 respectivcly.

The teacher evaluates the program by answering the questions on the Office Simulation Evaluation form on page 132.

Student Evaluation. Students will be given the traditional grades of A through $F$ to satisfy the requirements of the school. However, the plan of evaluation is designed to help the student grow and develop in all phases of job performance.

Each time a job transfer has been requested, the student will be evaluated by the supervisor and teacher using the following critcria for evaluation: 
(1) Quality of work (25 per cent of grade)

(2) Attitude toward work (25 per cent of grade)

(3) Effort and improvement (20 per cent of grade)

(4) Cooperation (15 per cent of grade)

(5) Attendance (10 per cent of grade)

(6) Attainment of knowledge and skill ( 5 per cent of grade)

The employee evaluation form supplied by the Lester Hill Corporation set will be used for both simulations. The evaluation will be discussed between the teacher and the student at which time constructive criticisms and guidance will be given the student.

The same criteria and method will be used at the end of each nine weeks and a grade will be assigned for the report card.

The final evaluation at the end of the year will be based on how well the student is prepared to meet the demands of the business world.

Instructional Materials

The following materials will be available in the classroom for use in the office simulation program:

(1) Agnew and Cornelia, Office Machines Course, South-Western Publishing Company, 1962.

(2) Agnew and Pasewark, Ten-Key Adding-Listing Machine and Printing Calculator Course, Third edition, South-Western Publishing Company, 1963.

(3) Andrews, Margaret E., About Her, Gregg Division/McGraw-lilll Book Company, 1969 .

(4) Andrews, Margaret E., About Ilim, Gregg Division/Mcfraw-Hill Book Company, 1968. 
(5) Andrews, Margaret E., It's Up to You, Gregg Division/McGraw-Hill Book Company, 1970.

(6) Andrews, Margaret E., The Job You Want, Gregg Division/McGrawHill Book Company, 1968.

(7) Andrews, Margaret E., You Pay for It, Gregg Division/McGraw-Hill Book Company, 1970.

(8) Andrews, Margaret E., You Said It, Gregg Division/McGraw-Hill Book Company, 1969.

(9) Archer, Brecker, and Stewart, General Office Procedures, Fourth edition, Gregg Division/McGraw-Hill Book Company, 1975.

(10) Archer and Stewart, Model Office Practice Set, Gregg Division/ McGraw-Hill Book Company, 1969.

(11) Archer, Stewart, and Seufer, Office Cashiering Practice Set, Gregg Division/McGraw-Hill Book Company, 1970.

(12) Bartholome, Lloyd W. and Marion B. Warner, Clerical office Typing, South-Western Publishing Company, 1972.

(13) Bassett, Agnew, and Goodman, Filing Office Practice, Third edition, South-Western Publishing Company, 1964.

(14) Boynton, Swanson, Carlson, Forkner, Century 21 Accounting, SouthWestern Publishing Company, 1972.

(15) Brendel and Leffingwel1, English Usage Drills and Exercises programmed for the Typewriter, Gregg Division/McGraw-Hill Book Company, 1968.

(16) Brendel and Near, Spelling Drills and Exercises programmed for the Typewriter, Gregg Division/McGraw-Hill Book Company, 1964.

(17) Brock, Luther A., How to Communicate by Letter and Memo, Gregg Division/McGraw-Hill Book Company, 1974. 
(18) Cleary, Joseph B., English Style Skill-Builders, Gregg Division/McGraw-Hill Book Company, 1967.

(19) Cotton, Lima, and Koeppen, llouston llouse, Gregg Division/

McGraw-liil1 Book Company, 1976.

(20) Dictionary of Bookkeejing and Accounting Terminology, SouthWestern Publishing Company, 1967.

(21) Duchan/Schultheis, Filing Business Names, South-Western Publishing Company, 1974.

(22) Duchan and Schultheis, Filing Personal Names, South-Western Publishing Company, 1974.

(23) Fasnacht, Bauernfeind, and Vigen, How to Use Business Machines, Third edition, Gregg Division/McGraw-llill Book Company, 1969.

(24) Fisher, Robert, Intensive Clerical and Civil Scrvice Training, Fourth edition, South-liestern Publishing Company, 1968.

(25) Fries and Clayton, Timed Writings About Careers, Second edition, South-Western Publishing Company, 1975.

(26) Friedman, Sherwood and Jack Grossman, Modern Clcrical Practice, Fourth edition, Pitman Publishing Corporation, 1975.

(27) Fries, Rowe, Travis, and Blockus, Applied Secretarial Procedures, Seventh Edition, Gregg Division/McGraw-llill Book Company, 1974 .

(28) Fruchling and Bouchard, Business Correspondence, Gregg Division/ McGraw-llill Book Company, 1971.

(29) Funk, Beverley, SAFECO, Washington Insurance Council, 1975.

(30) Gavin and Sabin, Reference Manual for Stenographers and Typists, Fourth Edition, Gregg Division/McGraw-Hill Book Company, 1970.

(31) llarrison, Martha and Janice Nesbet, Executive Dictation: Contemporary Style, J. Weston Walch, Publishing, 1968. 
(32) Henderson and Voiles, Business English Essentials, Fifth edition, Gregg Division/McGraw-Hill Book Company, 1975.

(33) Kestenbaum, A. Jack, Clerical Techniques for a Business Career, Allyn and Bacon, Inc., 1975.

(34) Krawitz, Myron J., Lester Hill Corporation, Gregg Division/McGrawHill Publishing Company, 1971.

(35) Krevolin and Nathan, The Gregg Office Job Training Program, Gregg Division/McGraw-Hil1 Book Company, 1972.

(36) Lessenberry, Crawford, and Erickson, Clerical Office Typing, South-Western Publishing Company, 1972.

(37) Liles, Brendel, and Krause, Typing Mailable Letters, Gregg Division/McGraw-Hill Book Company, 1960.

(38) McIntosh, Harriett and Clyde Welter, Executive Offices of America, South-Western, 1975 .

(39) Meehan, Oliverio, and Pasewark, Clerical Office Procedures, Fifth edition, South-Western Publishing Company, 1973.

(40) Meehan, Oliverio, and Pasewark, Secretarial Office Procedures, Eighth edition, South-Western Publishing Company, 1972.

(41) Morrison, Phyllis, Getting the Right Job, Gregg Division/McGrawHill Book Company, 1969.

(42) Morrison, Phyllis, Making the Most of Your Skills, Gregg Division/ McGraw-Hill Book Company, 1969.

(43) Morrison, Phyllis, Making the Most of Yourself, Gregg Division/ McGraw-Hill Book Company, 1969.

(44) Morrison, Phyllis, Opportunities in Today's Office, Gregg Division/ McGraw-Hill Book Company, 1969. 
(45) Mulkerne-Andrews, Civil Service Tests for Typists, Gregg Division/ McGraw-Hill Book Company, 1969.

(46) 100 Quickies for Business Education Classes, J. Weston Walch, Publisher, 1972.

(47) Pactor, Paul, Printing Calculator Course, Pitman Publishing Corporation, 1969.

(48) Pasewark, William R., Duplicating Machine Processes, SouthWestern Publishing Company, 1971.

(49) Pegboard Payroll System, South-Western Publishing Company, 1972.

(50) Pendery, John A. and Robert W. Fuller, Clerical Payroll Procedures, South-Western Publishing Company, 1970

(51) Perkins, W. E. Punctuation: A Programmed Approach, South-Western Publishing Company, 1972.

(52) Reynolds, Caroline, Snow Country, Typewriting Practice Set, SouthWestern Publishing Company, 1974.

(53) Ristau, Robert A., Exploring Clerical Careers, South-Western Publishing Company, 1974.

(54) Rosenberg, Henry J., Clerical Record Keeping, Third edition, South-Western Publishing Company, 1968.

(55) Schachter, Norman, English the Easy Way, Third Edition, SouthWestern Publishing Company, 1969.

(56) Skimin, Eleanor and Patsy McMurtrie, Office Style Dictation Tapes, Teaching Aids, Inc.

(57) The Executive Secretary's Word and Phrase Finder, Prentice-Hall, Inc., 1973.

(58) Today's Secretary, Gregg Division/McGraw-Hill Book Company. 
(59) Warren and Radcliff, Serendipity, Inc., South-Western Publishing Company, 1975.

(60) Weaver, llanna, Freeman, Brower, and Smiley, Accounting 10/12, Third edition, Gregg Division/McGraw Hill Publishing Company, 1977.

(61) West, Leonard J., 300 Commas, Gregg Division/McGraw-Hill Book Company, 1964.

(62) Wigge and Wood, Payroll Systems and Procedures, Gregg Division/ McGraw-Hil1 Book Company, 1970.

(63) Witherow, Mary, The Secretary on the Job, Gregg Division/McGrawHill Book Company, 1967.

(64) Wood, Merle W., Number Filing On the Job, South-Western Publishing Company, 1972.

Selection of Advisory Committee

The advisory committee will be selected during the year prior to the beginning of the office simulation class. The purpose of the committee is to assist the teacher in the following ways:

(1) help select and obtain the equipment and supplies needed for proper training stations

(2) recommend minimum standards of performance

(3) help in the development of forms to be used

(4) make recommendations of curriculum changes

(5) help select and secure resource speakers

(6) assist in surveys

(7) help with job placement after graduation

The committee shall consist of the following people:

(1) a full-time secretary

(2) an office manager 
(3) a business executive

(4) a guidance counselor

(5) a student

(6) a teacher

The comnittee will meet with the teacher at least three times a year--in the fall, winter, and spring.

School Acceptance of the Office Simulation Program

Before a new class can be added to the curriculum in the Reynolds schools, a proposal must be submitted to the Curriculum Council. The proposal to be presented to the Curriculum Council of the Columbia High School appears on page 134. 


\section{CHAPTER VI}

\section{SUMMARY, CONCLUSIONS, RECOMMENDATIONS}

This chapter consists of a suminary of the research effort, the findings of the study, the conclusions reached concerning the methods and materials used by office simulation teachers in Oregon, and the recommendations based on findings of this study.

\section{Summary}

The purpose of this study was to ascertain the methods and materials used by office simulation teachers in the secondary schools of Oregon and to suggest a plan to implement a simulated program in the Reynolds School District.

Questionnaires were sent to 170 secondary schools offering office practice classes. Of the 170 schools surveyed, 156 teachers returned the questionnaire for a 92 per cent response.

The data was tabulated and analyzed as it was received. The findings are presented in Chapter IV. The findings were combined with information obtained from related literature to develop an office simulation program suitable to be implemented at the Columbia lligh School for students from both Reynolds liigh School and the new Columbia High School. The plan of implementation is presented in Chapter V.

\section{Conclusions}

From the questionnaires returned, the following conclusions were drawn: 
(1) Sixty-five percent of the Oregon teachers responding to the survey teach office simulation in their business courses.

(2) Forty-six percent of the office simulation teachers offer an office simulation class separate from other classes.

(3) Many different titles are used for the office simulation class. The most frequently used titles are office simulation, model office, office practice, and office procedures.

(4) The classes most frequently incorporating units of office simulation are office practice and advanced typing.

(5) Most teachers teach office simulation in a full-year class.

(6) Typing I is required as a prerequisite to office simulation by most teachers.

(7) The junior year is the most popular year for students to take office simulation.

(8) Most schools offer office simulation one period per day five days a week.

(9) Lester Ili1l Corporation is taught by more schools than any other simulation materials available. Next in popularity are materials prepared by the individual teachers.

(10) Only six schools have the students do actual work for teachers and the community.

(11) Most of the equipment used for office simulation is cquipment already found in the school business classrooms.

(12) Quality of work and mailability are the evaluation criteria which receive the most weight in evaluating the performance of students in classes which include simulation units. Attitude toward work was ranked third out of ten critcria. 
(13) In the simulation class, independent of other classes, different evaluative criteria were ranked at the top of the list. Quality of work was ranked first, effort and improvement as second, and cooperation as third.

(14) The most popular length of time at one job position is four weeks.

(15) Most teachers select the students for job positions through.. student applications and interviews.

(16) More schools grant two credit hours for ten hours per week for a full year than any other way of assigning credits.

(17) The majority of the schools that offer office simulation have over 500 students in the student body.

(18) The more popular office simulation class size is from 11 to 20 students.

(19) Work-flow experience, depending on the work of others, and coordinating skills with demands on the job are facets of office simulation which are not learned in other classes.

(20) Office simulation was implemented in many of the schools because the teachers desired to have it as part of their program.

(21) Scheduling difficulties and teacher preparation time are the two main problems faced by teachers in setting up a simulation program.

(22) Student recommendations, counselor recommendations, and presentations in classes are the promotional methods used most often by the teachers of office simulation.

(23) The objective ranked first in importance to the office simulation program was to help students develop desirable work habits such as ability to organize, to follow directions, and to be thorough and efficient. 
(24) The objective ranked second was to develop acceptable character, personality traits, and work habits important to the business office.

(25) Most office simulation teachers in Oregon feel that the office simulation program is meeting the objectives desired.

\section{Recommendations}

The information gained from this study was used to plan a program of implementation for the Reynolds School District. The following recommendations are made as a result of the findings presented in this study: Recommendations for the Reynolds School District.

(1) An office simulation class should be included in the business curriculum of the Reynolds School District.

(2) The office simulation class should be taught at the new Columbia High School where the facilities and equipment can easily be set up as a model office.

(3) The office simulation class should meet two hours per day five days a weck for a full year.

(4) The simulation matcrials recommended to be used arc SAFECO, published by the Washington Insurance Council, and Lester Hill Corporation, published by the Gregg Division/McGraw-llill Book Company.

(5) The office simulation class should be called office simulation.

(6) Typing I should be a prerequisite to office simulation.

(7) The students should fill out application forms to be placed in job positions.

(8) Class size should be limited to 28 students.

(9) Job positions should be rotated about cvery four weeks. 
(10) Promotional methods should be used to publicize the office simulation class and to encourage students to enroll in it.

(11) An advisory committee should be selected.

(12) Office simulation graduates should be surveyed to determine where they are being employed and the requirements of their jobs. Recommendations for Needed Simulation Materials.

(1) More office simulation packages should be developed for use in the Portland area.

(2) The office simulation materials should be updated every three or four years to keep up with the changing business world. Recommendations for Further Study.

(1) Further study should be made to determine whether or not the graduates of office simulation are better prepared for office work than the graduates of the traditional office practice class.

(2) A study should be made to determine how much time should be spent on office simulation. Does a unit in office practice suffice or should it be a full-year class? 


\section{BIBLIOGRAPHY}

\section{Books and Magazines}

1. Ahlgren, Helen, and John Iskra, Jr., "Senior Business Lab," The Balance Sheet, Vol. XLVIII, No. 8 (Apri1, 1967), 351-333, 384.

2. Angela, Sister Marie, "Putting Practice into Office Practice," The Balance Sheet, Vol. L, No. 2 (October, 1968), 65-67, 96.

3. Archer, Fred C., "Full Value from Simulated Activities," Business Teacher, Vol. 45, No. 5 (May-June, 1968), 10-11.

4. Barger, Virginia, "Office Simulation, An Effective Technique," The Balance Sheet, Vol. LI, No. 6 (February, 1970), 259-261.

5. Barger, Virginia, "Simulation Provides Better Preparation for Office Employment," Business Education Forum, Vol. 24, No. 5 (February, 1970), 14-15.

6. Beaumont, Lee R., "Meet 'Mini-Sim'," Typewriting News (Spring, 1972), $1-3$.

7. Christian, Willard A., "An Office-Visitation Project--A Day in an Office," The Journal of Business Education, Vol. XLIII, No. 1 (October, 1967), 25-26.

8. Church, Olive, "Career Cluster Concept in Office Simulation," The Journal of Business Education, Vol. XLIX, No. 5 (February, 1974),

9. Church, Olive, "Occupational Model Plan: An Office Education Instructional Mode," The Delta Pi Epsilon Journal, Vol. XVI, No. 3 (May, 1974), 19-26.

10. Collins, L. M. "Word Processing in Business Education," Business Education Forum, (May, 1973), 32.

11. Collins, L. Millard, "Teach for Office Employment," National Business Education Association Yearbook, No. 5 (1967), 4-7.

12. Condor, Pat and Bill G. Rainey, A Study of Certain Aspects of Office Practice, (1972), 20-21.

13. Condor, Pat 0. and Bill G. Rainey, "The Current Status of Office Practice Courses," Business Education Forum, Vol. 27, No. 4 (January, 1973), 45-46. 
14. Conover, Hobart H. "Realism in the Classroom," Sincerely Yours, Vol. XVI, No. 32 (April, 1972), 4.

15. Drenth, N. A. "Simulation = Stimulation, Realism = Relevance," The Balance Sheet, Vo1. XLVII I, No. 2 (October, 1966), 61, 96.

16. Fritz, Noble V., "High School Programs," The Eastern Business Teachers Association Yearbook, No. 43, New Jersey (1970), 49-59.

17. Fruehling, Rosemary, "The Whole liorker: A Clerical Program Goal," Business Education Forum, Vol. 26, No. 5 (February, 1972), 17-18.

18. Funk, Beverly M., "A Blueprint for Successful Simulation," Business Education World, Vol. 24, No. 5 (February, 1970), 21- 22 .

19. Funk, Beverly M., "Simulation Plus Internship Equals Employability," Business Education Forum, Vol. 31, No. 1 (October, 1976) 30-32.

20. Gentzel, W. Eugene, "An Overview of Office Simulation," The Balance Sheet, Vol. LV, No. 3 (November, 1973), 104-106.

21. Hanson, Garth A., and Charles Parker, "Simulation," NBEA Yearbook, No. 10, (1972), 223-239.

22. Hanson, Garth A, and H. Robert Stocker, "Mobile Simulation in Office Education," Business Education Forum, Vol. 23, No. 1 (October, 1968), 17-18.

23. Hosler, Russel1, "Some Questions About Cooperative Education and Simulation Programs," Business Education Forum, Vol. 30, No. 8 (May, 1976) $8,10,12$.

24. Karsner, Jean C., "Successful Simulation Teaches office Practice," Business Education Forum, Vol. 27, No. 7 (April, 1969), 23-25.

25. Kilchenstein, Dolores, "Simulation in Business and Office Education," Business Education Forum, Vol. 24, No. 5 (February, 1970) 7.

26. Krawitz, Myron, "A Model Office," Business Education World, Vol. 52, No. 1 (September-October, 1971), 7-8.

27. Krevolin, "Bringing Reality Into the Classroom," Business Education World, Vol. 52, No. 4 (March-April, 1972), 6-7.

28. Kroeger, Ernest W., "Business Department--Nerve Center of the Entire School," California Business Education Journal, Vol. V, No. 3 (May, 1970) 2-8.

29. Lea, Barbara, "What Do Employers Want Your Students to Know?" Business Education Forum, Vol. 27, No. 2 (November, 1972), 54-55. 
30. Lee, John D. "Vocational Office Education .. . Indiana Style," Business Education Forum, Vol. 24, No. 5 (February, 1970), 12-14.

31. Lightner, Ardyce S., "Providing Job-Oriented Instruction in Block-Time Programs," Journal of Business Education, Vol. XLVII, No. 3 (December, 1971), 96-98.

32. Little, William J., "Businessman's View of Business Education," The Balance Sheet, Vo1. LVI, No. 4 (December, 1974/January, 19 $\overline{75}$ ), $160-161,187$.

33. Lynn, Helen, "Office Simulation Brings Stimulation and Enthusiasm" Business Education Forum, Vol. 30, No. 8 (May, 1976) 24-25.

34. Madden, Mary J., "Simulation in Office Education," NBEA Yearbook, No. 12, (1974), 149-156.

35. Marting, Barbara, "Preparing Typists for Modern Offices," NBEA Yearbook, No. 5, (1967), 105-108.

36. Moskovis, L. Michael, "Simulation Revisited," The Balance Sheet, Vol. LII, No. 3 (November, 1970), 104-106, $13 \overline{3}$.

37. Mycrs, Charles, "Secretarial Education in an Office-Like Environment." The Balance Sheet, Vol. LI, No. 9 (May, 1970), 396-397, 421.

38. Nea1, Dorothy A., "Office Simulation: What it is and Where it's Going," Business Education World, Vol. 56, No. 3, (January-February, 1976), 3-5.

39. Poland, Robert, "Block-Time Approach in Office Education," NBEA Yearbook, No. 8, (1970), 263-269.

40. Poland, Robert, "Block-Time Program in Office Education," Review: Catholic BEA, Vol. XXI, No. 3 (Spring, 1970) 29-40.

41. Poland, Robert, "Various Types of Simulated Office Programs," Business Education Forum, Vol. 27, No. 8 (May, 1973), 22-24.

42. Popham, Este1le L., Making Business Education Meaningful with a Competency-Based Curriculum," Business Education World, Vol. 55, No. 5 (May-June, 1975), 5-6, $2 \overline{9}$.

43. Quigley, Elizabeth J., "Call It Office Procedures," The Journal of Business Education, Vol. XLVI, No. 7 (April, 1971), 289-290.

44. Ringersen, Carolyn, "A Model office in the lligh School," Business Education Forum, Vol. 24, No. 1 (October, 1969), 22-23.

45. Ruddle, Eleanor, "Model office at Hayfield Secondary," VBEA Newsletter (September, 1971), 12-14. 
46. Sabin, William A. "Simulation in the Seventies: An Overview," Busi-

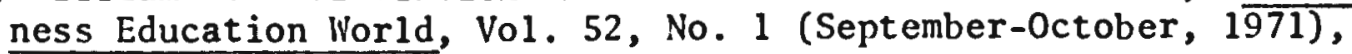
5-7.

47. Sawaia, Josephine, "Block-Time Approach Meets Student Needs," Business Education Forum, Vol. 24, No. 5 (February, 1970), $\overline{10-12}$.

48. Schatz, Anne E., "Simulation in Office Machines," Journal of Business Education, Vol. XLV, No. 1 (October, 1970), 17-18.

49. Schmidt, June, "Office Observation Shows Need for Attitude Training," Business Education Forum, Vol. 24, No. 5 (February, 1970), 9-10.

50." Skaret, Wayne E., "A Follow-up Study of Model Office Program at Clovis, California," California Business Education Journal, Vol. VIII, No. 1 (October, 1972), 10-11.

51. Smith, Genevieve, "The Mini-Company: A New Approach to Office Education," Journal of Business Education, Vol. XLIX, No. 2 (November, 1973), 54-56.

52. Sne11, Walter, "Projections for the Future," NBEA Yearbook, No. 6, (1968), 34-46.

53. This, Leslie E., "What is Simulation?" American Vocational Journal, Vol. 45, No. 6 (September, 1966), $20-22$.

54. Thomas, Ellis R., "Block-Time Instruction: A Laboratory Approach," NBEA Yearbook, No. 12, (1974), 144-148.

55. Tonne, Ilerbert A., "Training for the Job Versus the Role," The Journal of Business Education, Vol. XLII, No. 1 (October, 1966), 12-13.

56. Uthe, Elaine, "Class Organization," The Eastern Business Teachers As sociation Yearbook, No. 43, New Jersey (1969), 133-142.

57. Wine, Mary Butera, "Office Practice/Simulated Work Experience," The EBTA Journal, Vol. IX, No. 2 (Spring, 1971), 50-54.

58. Wingo, Rosetta, "Simulation with Movement," The Balance Sheet, Vol. LIII, No. 1 (September, 1971), 10-12.

59. Witherow, Marty, "An Up-to-Date Secondary Clerical Program," Business Education Forum, Vol. 25, No. 5 (February, 1971), 17-18.

60. Wunsch, Alan P., "Model Office Simulation Improves Interpersonal Relations," Business Education Forum, Vol. 29, No. 4 (January, 1975), 5-7. 
Office Simulation Materials

61. Block Time-Simulation: Individualized office Instructional System Research and Development Program in Vocational-Technical Education, Department of Secondary Education and Curriculum, Michigan State University, Vol. 1, (July, 1969).

62. Funk, Beverley, SAFECO, Washington Insurance Council, (September, 1975).

63. Krawitz, Myron J. Lester Hill Corporation, Gregg Division/McGrawHill Book Company, (1972). 
COVER LETTER

15848 S. E. Stephens Ct.

Portland, OR 97233

March 28, 1977

Name of Class Instructor

Name of School

Address

City, State ZIP

Dear Fellow Educator:

In the fall of 1978, I plan to implement a simulated office as part of the business education offerings in the Reynolds School District high schools. I am interested in finding out how other schools in Oregon are handling office simulation. The plan for the simulated office program at Reynolds will be included in my Master's Thesis at Portland State University.

Would you please complete the enclosed questionnaire and return it to me in the self-addressed, stamped envelope. If the answer to Question 1 is no, I would still appreciate receiving the questionnaire back as that information is also important to my study.

The data I receive will be tabulated and I will be happy to send you a copy of the results. If you have a simulated office, it may be helpful in evaluating your program; or if you have no simulated office, it may be of interest to you in determining whether or not you should offer such a program.

Your help in this project will be greatly appreciated.

Sincerely,

Mrs. Arlene Krause

Enclosures 
OFFICE SIMULATION QUESTIONNAIRE

NAME OF SCHOOL

ADDRESS OF SCHOOL

NAME OF PERSON COMPLETING QUESTIONNAIRE

1. Do you have any form of office simulation in your business curriculum? IT Yes IT No If answer is no, please return questionnaire.

2. Name of simulation class

3. If simulation is a part of another class, please given name(s) of class(es)

4. How long is the simulation class taught?
T a unit in another class
IT nine-week class
IT one-semester class
IT integrated with other classes
$\square$ full-year class
IT other

5. What are the prerequisites of the simulation class?
$I T$ Typing I
IT Business Machines
IT Soph. Standing
$I$ Typing II
IT Shorthand I
IT Jr. Standing
IT General Business
II Business Math
IT Sr. Standing
$I$ Bookkecping/Accounting
$1 T$ GPA IT Teacher Approval
$I$ other

6. For what block of time does the simulation class meet?
IT 5 hours $(50 \mathrm{~min})$ per week
IT 15 hours per week
IT 10 hours per week
$I T$ other

7. What text or materials are used for simulation?
IT Serendipity, Inc.
L Gregg office Job Training
IT Lester Hill Corp.
IT American Paper Exporting Assn (APEX)
IT Indio Paper Co., Inc.
$I T$ Executives Offices of America
IT Personal materials
IT other 
8. What equipment is used in the simulation?

$I 7$ spirit duplicator

IT mimeograph

IT offset machine

II photocopier

IT electric typewriters

IT manual typewriters

IT long carriage typewriter

IT executive typewriters

IT transcribers

IT projector

IT memory typewriter

IT collator

II others
IT posting machine

IT overhead

IT postage meter

IT filing cabinets

II Thermofax

IT key-driven calculator

IT electronic calculator

IT ten-key adding machines

IT practice telephone equipment

IT key punch machine

IT full-kcyboard listing machine

IT mimeoscope

9. Rank the following criteria used for evaluating students according to the value placed on that item. Use "l" for the item on which is placed the most weight, "2" for the next most heavily weighted item, etc.

IT quality of work

IT quantity of work

IT mailability

IT cooperation

IT attendance

IT other
IT effort and improvement

II attainment of skill and knowledge

IT attitude toward work

IT initiative

IT meeting deadlines

10. How often are job positions rotated?

IT 1 week

IT 4 weeks

IT 6 weeks
179 weeks

II not rotated

II other 
11. Ilow are students selected for job positions?

$I T$ student application $I T$ weaknesses of student $I T$ interviews $I T$ ability of student II recommendations IT other

12. How many credits per year are given simulation students?

IT $1 / 4$ IT $1 / 2$ IT 1 IT 2 IT other

13. How many students are enrolled in your school?

IT 0-99 IT 100-299 IT 300-499 IT 500-999 IT over 1000

14. How many students are enrolled in office simulation?

IT $0-10$ IT 11-20 IT 21-30 IT over 30

15. How many classes of simulation are offered?

$I I 1 \quad 1 \quad 2 \quad 3 \quad$ IT other

16. What learning takes place that students cannot get in other classes taught in your school, such as office practice and work experience?

$I$ work-flow experience II maturity development

$I$ depending on work of other workers IT letter composition

$I$ closely supervised work experience $I T$ other

$I$ coordinate skills with on-the-job demands

17. Why was the program implemented in your school?
$I$ demands of business
$I$ recommended by advisory committee
$I$ demands of students
$I T$ recommendation of fellow educators
IT available funds
$I T$ self-desire
$I$ other

18. What problems were encountered in setting up the simulation program?

I lack of funds

IT lack of equipment

IT scheduling difficulties
II teacher preparation time

IT lack of student interest

IT other 
19. What promotional methods are used to encourage students to take the simulation class?

IT brochures

$I T$ slides

IT movies
I presentations in other classes

$I T$ student recommendations

IT counselor recommendations

IT other

20. Please rank the following objectives as to their importance to your simulation program. Rate the most important as "l", the second most important as "2", etc.

TT To develop acceptable character, personality traits, and work habits important to the business office.

IT To improve and coordinate office skills learned in other courses.

$I T$ To understand the organization and flow of work of the business office.

IT To build a background knowledge of business principles, office organization, and occupational information.

$I T$ To develop an acquaintanceship skill in the use of machines commonly found in an office.

$I T$ To further develop skills in the typing of various business forms and in proofreading.

To develop skill in filing and in records management.

To develop work simplification techniques in the office.

To develop skill in looking for and in applying for an office position.

To provide an informational background of performed duties which a beginner in an office may be called upon to perform.

To help develop occupational maturity by enriching their background of business information.

17 To acquaint students with business standards and requirements.

IT To help students develop desirable work habits such as ability to organize, to follow directions, and to be thorough and efficient.

IT To provide opportunity for students to develop the ability to evaluate their work and the work of others.

IT other

21. Is the simulation class meeting the objectives desired? $I T$ Yes IT No IT Don't know

22. Any additional comments would be greatly appreciated. 
FOLLOW-UP LETTER

15848 S. E. Stephens Ct.

Portland, OR 97233

May 2, 1977

Name of class instructor

Name of school

Address

City, State ZIP

Dear Fellow Educator:

In March, I sent you a copy of the enclosed questionnaire; and as of this date, I have not received the completed form. I realize that the end of the year is a busy time for teachers and that the question-. naire may have been lost in the shuffle of trying to wind up the year.

Consequently, I am sending another questionnaire which I would appreciate having you complete and return to me before June 10 . Another stamped, self-addressed envelope is enclosed for your convenience in returning the questionnaire to me.

Next to a controlled work experience, a simulated office provides the student the best way to prepare for the field of office work. It helps to bridge the gap between the school and the office. Therefore, the results of this survey may be of help to you in your business education curriculum.

Your assistance in helping me with this project will be greatly appreciated.

Sincerely,

Mrs. Arlene Krause

Enclosures 
COLUMBIA HIGH SCIOOL

\section{QUESTIONNAIRE FOR JOB-PLACEMENT SURVEY}

1. What jobs do you have available to high school graduates? (please check)

Stenographers - Office Receptionist

General Clerk

Typist Clerk

- Stock Clerk
Doctor's Assistant Dentist's Assistant Switchboard Operator Bookkecper-Stenographer

Assistant Bookkeeper
Voice-Machine operator Payroll Clerk

File Clerk

Stock Boy

Machine Repairman

Do you prefer male or female personnel for the jobs?

2. What duties would they perform? (Please check)

Typing:

Transcription
-Invoices
- Bills
- Other office forms

$\longrightarrow$
Dictation

Telephone

Receptionist Bookkeeping
Combinations:

Payroll-Clerical

Shipping-Clerical

Filing-Clerical

3. What are your skill requirements?

Typing: Words Per Minute Dictation: Words Per Minute

Production

4. What office machines will they be expected to use?

Typewriter: Manual $\because$
Ten-Key Adding Machine: Manual

Ful1-Bank Adding Machine: Manual

Mimeograph: Manual

Duplicator: Manual Electric

Name Memory

Calculator: Name Electric Electric Name

Photocopy: Name

Posting Machine: $\overline{\text { Name }}$

Dictaphone: Kind

Others:

Do you prefer to train your own personnel in machine operation?

Do you require a basic skill in machine operation?

5. Do you have openings at present?

Do you see possibilities of openings in the near future? (continued) 
How do you wish applicants to contact your office for appointments?

When may applicants contact you?

6. What kinds of tests do you give applicants?

Skill:

Publisher:

Personality

Publisher

7. What are some of the personal traits that you think are most important? (Please check)

\begin{tabular}{lll} 
Tact & \multicolumn{1}{c}{ Social Attitude } & Others \\
Voice and Diction & Initiative & \\
- Expression & Manners \\
\hline Sense of Humor & - Good Grooming
\end{tabular}

8. What is your approximate beginning salary?

9. What weaknesses have you found in the high school graduate on his or her first job?

10. Comments

NAME OF BUSINESS

ADDRESS

KIND OF BUSINESS

EMPLOYER

OFFICE HOURS

TELEPHONE NUMBER 
NAME" OF BUSINESS:

ADDRESS:

KIND OF BUSINESS:

1. Jobs Available:

2. Duties Performed:

3. Skills Required:

4. Machines Used:

5. Openings: Yes No Contact: (letter, telephone, personal interview)

6. Tests Given:

7. Personal Traits Needed:

8. Salary:

9. Weaknesses of Former Employees:

10. Comments: 
Prior to registration for next year, it is necessary to determine the number of students who wish to enroll in the Office Simulation Program. Therefore, we are asking that you complete the information requested at the bottom of this page and return it to your business teacher by the end of this week.

Office Simulation is a two-credit course which meets for two hours a day for the full school year. A complete description of the course is provided in the Course Description Handbook.

Pre-Requisites and Requirements for Enrollment

1. The Office Simulation is for seniors, graduating juniors, or juniors who plan to take the class for two years.

2. The student must have successfully completed Typing I.

3. The student must have a good attendance record.

4. The student must have an interest in an office career, must demonstrate ambition and initiative, and must be a responsible person.

Please complete the following form:

I wish to enroll in the Office Simulation Program.

I may be interested.

I am not interested. 
APPLICATION FOR OFFICE SIMULATION PROGRAM

Name Address

Phone Birthplace Birthdate

Age Sex Guide Teacher

Counselor

What is your health condition? Good Fair Poor Do you

have any physical defects? Explain

Father or Guardian Address

Mother or Guardian Address

Father's Occupation Mother's Occupation

liow many times have you been absent from school this year?

Tardy How do you consider your record as a student? (Circle one)

A B C D F

High School Business Subjects That You Will Have Completed After This Year

\begin{tabular}{|l|l|l|}
\hline 9 th Subject & 10th Subject & 11th Subject \\
\hline & & \\
\hline & & \\
\hline
\end{tabular}

What is your typing speed?

Shorthand speed?

What other machines can you operate?

Which type of job would you prefer to have (check in order of your preference 1, 2, 3)

Bookkeeper

- Cashier (handle petty cash, payroll)

- Clerical Worker-Typist

Data Processing (computer)

File Clerk

Receptionist

- Stenographer-Secretary

- Transcription Machine

Typist

Other

Are you working now? Where Type of Work

What do you plan to do after you graduate from high school? 
References: (Only two may be teachers and none may be relatives)

Name

Address

Occupation

Phone

Please answer the following questions using complete sentences. Type your answers to questions $1-3$ and answer question 4 in your own handwriting. Return this to your business teacher.

1. Why do you want to participate in this program?

2. What do you hope to be doing five years from now?

3. What subjects do you enjoy the most?

4. In what school or social organizations do you participate actively? (Please answer this question in your own handwriting.)

IF I AM ACCEPTED FOR TIIIS PROGRAM, I PLEDGE MYSELF TO TAKE ADVANTAGE OF EVERY OPPORTUNITY TO INCREASE MY EFFICIENCY AND SKILL AS AN OFFICE WORKER IN BOTH TIIE CLASSROOM AND ON TIIE JOB 
OFFICE SIMULATION PROGRAM PERSONAL INTERVIEW FORM

(To be completed by interviewer)

Name

Date

What reasons prompted you to apply for the office simulation class?

What do you plan to do after graduating from high school?

What career do you wish to pursue?

Why?

Which class do you like most? Least?

What are your hobbies?

What extra curricular activities do you enjoy?

What offices have you held in these activities?

Have you held an office in activities other than school?

How many days were you absent last year? Why?

How many brothers do you have? Sisters? Number older?

Number younger? ___ What do you know about this program for which you are being interviewed?

What do you think you will gain from being in this program?

What do you think would be the most interesting thing about working in an office?

What do you think you would dislike most about an office job?

Are you working now? If yes, where?

What are your duties?

How long have you been with this firm? beginning wage?

In what subjects do you think you need more work? (continued on next page) 
In what type of business or office would you like to work?

In which of the office skills do you think you are most skilled?

Do you think you are qualified for office work?

The simulated office is an office of a company set up within the school. The students will be expected to conduct themselves as if they were in a real office.

What do you consider to be the proper dress for an office employee?

What do you consider to be the proper behavior for an office employee?

If you were to be accepted into the office simulation program, would you be willing to conduct yourself as if you were in a real office?

*If you were working in an office and the person working next to you talked constantly, therefore keeping you from getting your work done, what would you do?

*You are on your way to an interview and your best friend comes along and is persistent about going with you and waiting in the reception room, what would you do?

*After working for a week on a committec report, which included five carbon copies, your boss has returned the report with several typographical errors circled and misspelled words... insisting that he needs it by tomorrow afternoon. What would your reaction be?

*Organization policy states that coffee breaks are 15 minutes long; the group that you are sitting with isn't finished with their conversation and 15 minutes have gone by. What would you do?

* What should an individual do if he is told to do something by his teacher (or his employer) and he feels that such action is not necessary or he feels that he knows of a better way of accomplishing the same results? 
Ratings: 1 Highly Acceptable

2 Acceptable

3 Doubtful

4 Not Acceptable

\begin{tabular}{|c|c|c|c|}
\hline Quality & 1 & 3 & 4 and Why \\
\hline Personal appearance & & & \\
\hline Poise (self confidence) & & & \\
\hline Speech (tone and grammar) & & & \\
\hline Personality & & & \\
\hline Attitude & & & \\
\hline Ability to make decisions $(*)$ & & & \\
\hline Social courtesies & & & \\
\hline Acceptance of policies $(\star)$ & & & \\
\hline Mannerisms & & & \\
\hline
\end{tabular}

(61:II-16) 


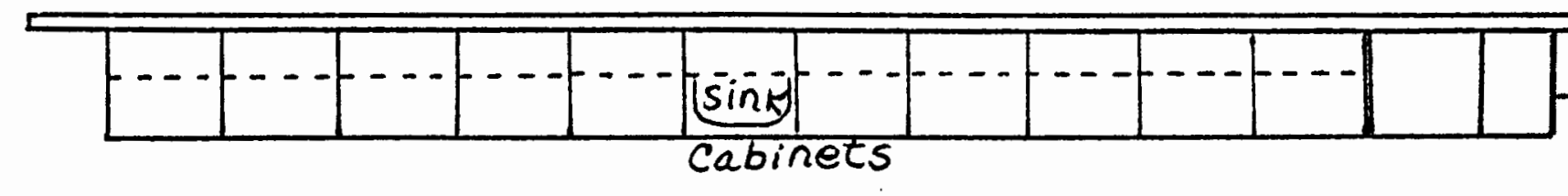

Business Machines

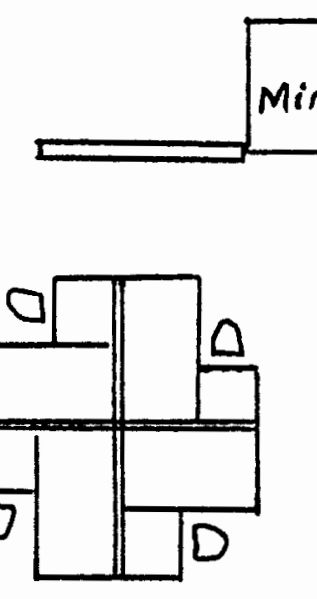

\begin{tabular}{|c|c|c|c|}
\hline Mimeograph & $\begin{array}{c}\text { Spirit } \\
\text { duplieator }\end{array}$ & $\begin{array}{l}\text { Work } \\
\text { table }\end{array}$ & Xerox \\
\hline
\end{tabular}

Thermofax
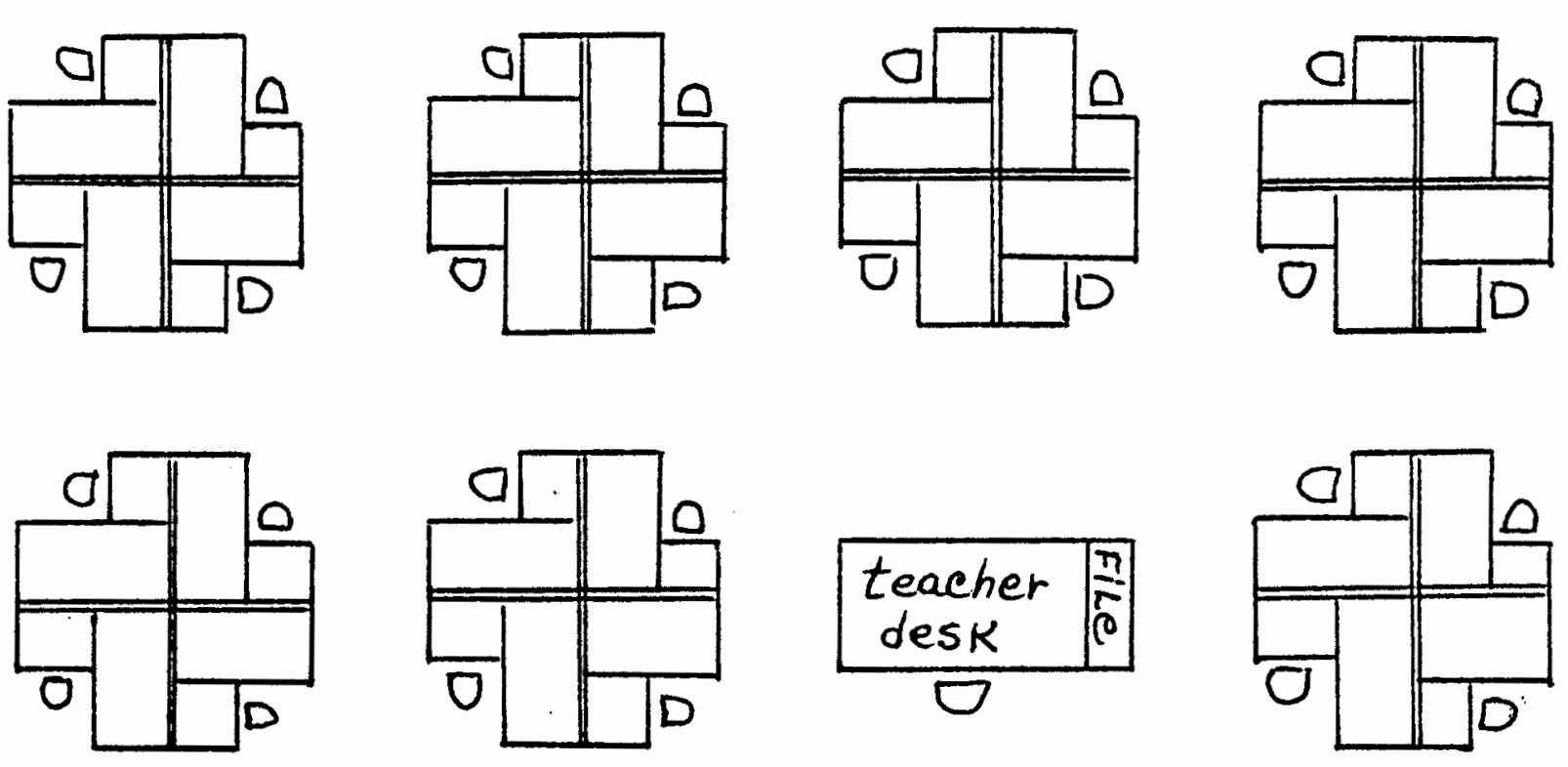

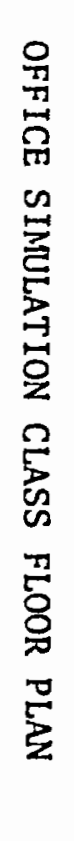

Chalkboard 
COVER LETTER FOR

FOLLOW-UP SURVEY OF OFFICE SIMULATION GRADUATES

Dear

In an effort to provide our business education students the best office simulation program, we are currently cvaluating the program at Columbia High School. We are interested in knowing how each of our graduates are doing in the business field and whether or not our program has been of value to you.

Would you please fill out the enclosed questionnaire and return it in the enclosed stamped, self-addressed envelope. Your help in our evaluation will be greatly appreciated.

Why don't you stop by the school one of these days and share your experiences with us. We would love to see you again.

Sincerely yours,

Mrs. Arlene Krause

Office Simulation Teacher

Enclosures: Survey form

Reply envelope 
FOLLOW-UP SURVEY OF OFFICE SIMULATION GRADUATES

Name of high school from which you graduated Year you graduated

Please check the correct answer for each question in this section.

1. Check one:
( ) Male
( ) Female

2. Check one:
( ) Married
( ) Single

3. Check one:
( ) Employed full time for pay
( ) Employed part time for pay
( ) In military service
( ) Not employed for pay (check reason)
( ) Illness
( ) Full time homemaker
( ) Seeking employment
( ) Not seeking employment
( ) Going to school or college
( ) Other

4. If you were employed during your final year in high school, did you work:

( ) One month or less

( ) 2 to 5 months

( ) 6 months or more

5. If you were employed during your final year in high school, were you doing office work similar to that covered in the Office Simulation Class?

( ) Yes

( ) No

If you have been employed since graduation from high school, please check or complete the appropriate questions in this section.

6. Was your first job after graduation from high school:

( ) Full time

( ) Part time

7. How did you get your first job after graduation?

( ) Through a friend or relative

( ) Through your high school

( ) Through another school

( ) Through a Civil Scrvice Exam

( ) Through a State Employment Scrvice

( ) Through a private employment agency

(continued) 
( ) By answering an advertisement

( ) By applying directly to a person or company that might be hiring

( ) Through a union or bargaining group

( ) Other

8. After you started seeking employment, how long did it take you to find the first job you had after high school?

( ) I found it before I left high school

( ) Less than a week

( ) 1 to 2 weeks

( ) 2 to 4 weeks

() 1 to 2 months

() 2 to 4 months

( ) 4 to 6 months

( ) Longer than 6 months

9. How many different positions have you had since you left high school?

( ) None

( ) One

( ) Two

( ) Three or more

10. If your present position is different from your first position, is it with:

( ) the same firm

() a different firm

11. What was the job title of your first job after graduation?

12. What were your most important duties on your first job? Please be specific.

13. If you indicated a different firm in the preceding question, how did you get your current position?

( ) Through a friend or relative

( ) Through your high school

() Through another school

( ) Through a Civil Service Exam

( ) Through a State Employment Service

( ) Through a private employment agency

( ) By answering an advertisement

( ) By applying directly to a person or company that might be hiring

( ) Through a union or bargaining group

( ) Other

14. What is the type of business of your present employer? 
15. Approximately how many employees work for your present employer?

(Number in your branch if part of a larger firm)

( ) $1-49$

( ) $50-99$

( ) $100-249$

( ) $250-749$

( ) 750 or more

16. What is your present job title?

17. What are your most important duties on your present job? (Please be specific)

18. How well do you like this job?

( ) Very well--(I like all the activities)

( ) Fairly well--(I like most of the activities)

( ) Not very well--(I don't like many of the activities)

( ) Not at all--(I don't like the job)

19. How long do you plan to stay in this type of work?

( ) I plan to make it my career

( ) At present I have no plans to change

( ) Probably a few years

( ) I plan to change soon

PLEASE: EXPLAIN WHY

20. What is your pay (before deductions) on your present job? (Please

fill in ONE of the lines below)

( ) $\$$

( ) $\$$ per hour

( ) $\$$ per week per month

21. Where do you work?

\section{City} County

State

22. Do you work within commuting distance from your high school?

( ) Yes

( ) No

23. Check the statement that best describes where you work:

( ) I work within ten miles from the high school from which I graduated

( ) I work more than ten miles but less than fifty miles from the high school from which I graduated

( ) I work more than fifty miles from the high school from which I graduated but still in the same state

( ) I work in another state 
24. How many pay increases have you received since graduation?
( ) None
( ) One
( ) Two
( ) Three or more

25. How many promotions have you received since graduation?
( ) None
( ) One
( ) Two
( ) Three or more

26. Since graduation, how much additional formal training have you received from an employer?
( ) None
( ) One or less days
( ) Two days
( ) Three to five days
( ) Five days or more

27. If you received additional training on the job, what was the purpose of this training?
( ) To do the regular job
( ) To perform special tasks
( ) For promotion
( ) Other

28. List the kinds of training, if any, you have received through an employer:

29. In reference to your present job, which three of the following are most important to you? MOST IMPORTANT (Please rank in order of importance--1, 2, and 3)
( ) Starting salary
( ) Working conditions
( ) Job security
( ) Good supervisors
( ) Good fellow workers
( ) Importance of work
( ) Opportunity from promotion
( ) Good fringe benefits
( ) Serving others
( ) Personal interest in work
( ) Location
( ) Other

30. In reference to your present job, which three of the following are least important to you? LEAST IMPORTANT (Please rank in order of least importance--1, 2, and 3)

( ) Starting salary

( ) Working conditions 

( ) Job security
( ) Good supervisors
( ) Good fellow workers
( ) Importance of work
( ) Opportunity for promotion
( ) Good fringe benefits
( ) Serving others
() Personal interest in work
( ) Location
( ) other

31. How have you used the professional skills and attitudes developed in the Office Simulations class? (CHECK AS MANY AS APPLY)
( ) Seeking a job
( ) Applying for a job
( ) Maintaining a job
( ) Receiving promotions

Please answer the following questions if you are or have attended a school or college since your high school graduation.

32. Have you attended a school or college after graduation from high school?

( ) Yes

( ) No

33. If you answered yes, are (or were) you enrolled

( ) Full time

( ) Part time

34. If you are attending a school or college, what kind is it?

( ) Four-year college

( ) Public junior or community college

() Business school

( ) Trade school

() other

35. What is (or was) your major course of study?

36. Are you partially financing your education through using the skills and knowledges you gained in your office Simulation class?

( ) Yes

( ) No

37. Did the Office Simulation class training influence your choice of your college major?

( ) Yes

( ) No 
38. Your personal estimate of the value of office Simulation training.

In Column I check all subjects or units you consider very valuable. In Column II check all subjects or units you consider of little value.
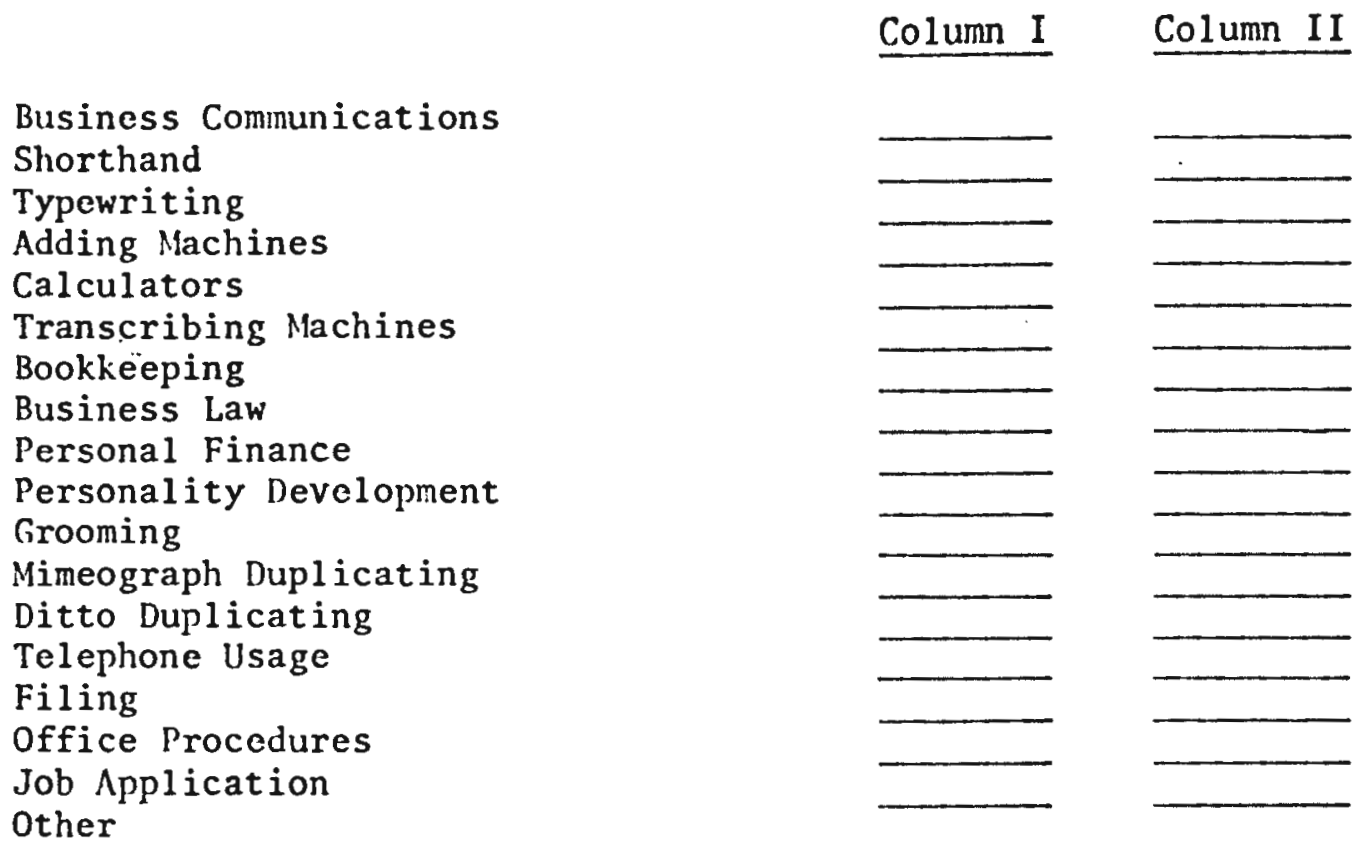

Please complete this section so our records will be accurate.

39. Your name and address:

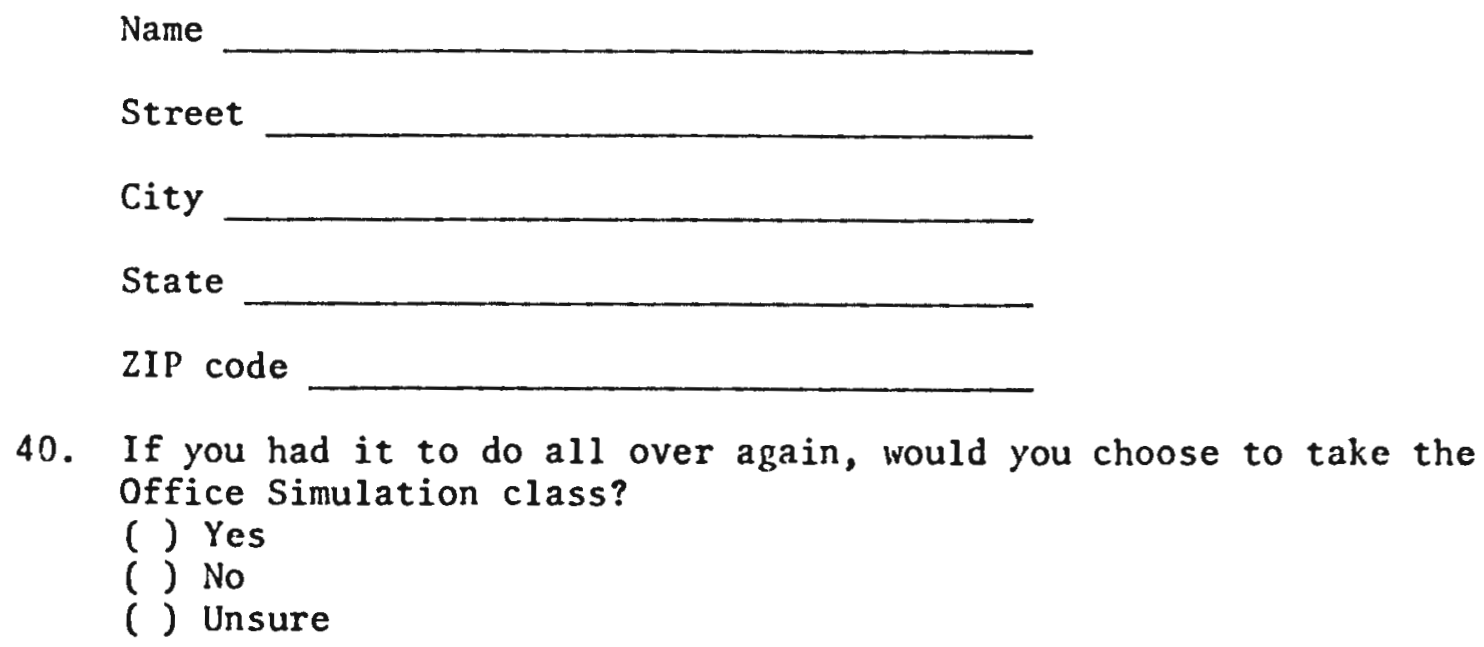

40. If you had it to do all over again, would you choose to take the Office Simulation class?

( ) Yes

( ) No

( ) Unsure

TILANK YOU FOR IIELPING US TO IMPROVE OFFICE EDUCATION! 
COVER LETTER FOR

EMPLOYEES RATING FORM

Dear Sir or Madam:

In evaluating the office simulation program at Columbia liigh School, the reactions of employers to our graduates will help us determine the value and effectiveness of our program.

Would you please have the supervisor of the employee named on the evaluation form fill out the form and return it to me in the enclosed stamped, selfaddressed envelope. An instruction sheet is attached to the evaluation form. If the person on the evaluation form is no longer in your employ, I would still appreciate having an evaluation of that person if at all possible.

Your help in cvaluating our office simulation program will be greatly appreciated.

Sincerely yours,

Mrs. Arlene Krause

Enclosures: Instruction sheet

Rating form

Reply cnvelope 


\section{INSTRUCTIONS TO RATERS}

1. Read the evaluation form thoroughly before rating the employee.

2. Base judgments upon entire employment period.

3. Compare employee with others in a similar position.

4. Evaluate each trait separate from others.

5. Check the appropriate number for each trait.

6. The rating scale to be used is:

$$
\begin{aligned}
& 1=\text { Extraordinary } \\
& 2=\text { Very good } \\
& 3=\text { Satisfactory } \\
& 4=\text { Barely acceptable } \\
& 5=\text { Inadequate }
\end{aligned}
$$


EMPLOYEE RATING FORM

Employee's Name

Employee's Job Title

\begin{tabular}{|c|c|c|c|c|c|}
\hline TRAITS & 1 & 2 & 3 & 4 & 5 \\
\hline $\begin{array}{l}\text { QUANTITY OF WORK: } \\
\text { Consider number of assignments completed and volume of work in rela } \\
\text { tion to the work performed by others in a similar position. }\end{array}$ & & & & & \\
\hline $\begin{array}{l}\text { QUALITY OF WORK: } \\
\text { Consider all acceptable work according to thoroughness, accuracy, a } \\
\text { orderliness compared to work performed by others in a similar posit }\end{array}$ & & & & & \\
\hline $\begin{array}{l}\text { INITIATIVE: } \\
\text { Does the employee find new ways of doing things, does things withou } \\
\text { being instructed, and find new things to do as compared to other } \\
\text { workers in a similar position? }\end{array}$ & & & & & \\
\hline $\begin{array}{l}\text { DEPENDABILITY: } \\
\text { Does the worker complete the assigned jobs on time without a lot of } \\
\text { supervision? }\end{array}$ & & & & & \\
\hline $\begin{array}{l}\text { PUNCTUALITY AND ATTENDANCE: } \\
\text { Consider if the employee arrives to work on time and is regular in } \\
\text { attendance }\end{array}$ & & & & & \\
\hline
\end{tabular}

(continued) 


\begin{tabular}{|c|c|c|c|c|c|}
\hline TRAITS & 1 & 2 & 3 & 4 & 5 \\
\hline $\begin{array}{l}\text { JUDGMENT: } \\
\text { Does the worker use good judgment in the absence of detailed in } \\
\text { structions and in unusual situations? }\end{array}$ & & & & & \\
\hline $\begin{array}{l}\text { APPEARANCE: } \\
\text { Does the employee make a good impression on others as to person } \\
\text { grooming, neatness, and cleanliness? }\end{array}$ & & & & & \\
\hline $\begin{array}{l}\text { ATTITUDE TOWARD OTIIERS: } \\
\text { Docs the employee accept others as they are and treat them as e }\end{array}$ & & & & & \\
\hline $\begin{array}{l}\text { VALUE TO ERIPLOYER: } \\
\text { Review all factors previously listed and determine how valuable } \\
\text { the cmployee is to your firm. }\end{array}$ & & & & & \\
\hline
\end{tabular}


OFFICE SIMULATION EVALUATION

(to be completed by teacher)

Yes № Partially

1. Are the course content and work

stations based on the individual

needs and objectives of the

students?

2. Are the course content and work stations approved by the advisory committee?

3. Are the instructional materials appropriate for the work station?

4. Do the instructional materials detail the duties of each work station

5. Do the instructional materials allow the student to assume the role of an office worker?

6. Do the instructional materials allow the student to apply office procedures and techniques?

7. Do the instructional materials allow the students to pursue their interests?

8. Do the instructional materials permit the student to strengthen weaknesses in basic skills and knowledges?

9. Does the simulated office permit the students the opportunity to work at their own pace?

10. Does the office simulation class encourage students to act and dress as they would in a real office?

11. Are the students given a variety of activities to do? 
12. Are goals set and strived for?

13. Are social activities included in the program?

14. Are office standards of quality and production adherred to?

15. Is the equipment and facilities used up to date and appropriate?

16. Does the student evaluation consider individual differences?

17. Is the student evaluation comparable to the evaluation used in offices? 
MEMO TO CURRICULUM COUNCIL

FOR PROPOSED OFFICE SIMULATION CLASS

To: Curriculum Council Members

From: Arlcne Krause

Subject: Proposed Office Simulation Class

Date:

It is the desire of the Business Department to implement an office simulation class into its curriculum in September, 1978.

It is proposed that the class be a two-hour block five days a week with two credit hours given to the students successfully completing the program.

The class will simulate two different businesses offering the students a variety of experiences in office work.

The office simulation class is an effective way of preparing office workers for the following reasons:

1. Specific skills and knowledges are combined into meaningful exercises to provide relevancy to the actual office situation.

2. Students have the opportunity to actually perform the duties of office workers.

3. Students improve their human relations by learning to work together through stress situations.

4. The tasks the students perform motivate them to build their skills.

5. Decision-making is emphasized.

6. Teaching is directed toward preparing the student for a vocation.

7. The student is guided toward his carcer objective through individualized instruction and guidance.

8. The teacher is able to combine many areas of instruction into meaningful office simulation activities.

9. Businesses become more involved in the school by helping the teacher develop realistic office projects.

10. The students understand the organization and work flow of the business office.

One division of the simulated company is the stenographic pool which will do production typing for the office and teachers. 